\title{
Picoplankton community structure before, during and after convection event in the offshore waters of the Southern Adriatic Sea
}

\author{
M. Najdek ${ }^{1}$, P. Paliaga ${ }^{1}$, T. Šilović ${ }^{1}$, M. Batistić ${ }^{2}$, R. Garić ${ }^{2}$, N. Supić ${ }^{1}$, I. Ivančić ${ }^{1}$, S. Ljubimir ${ }^{2}$, M. Korlević ${ }^{1}$, \\ N. Jasprica ${ }^{2}$, E. Hrustić ${ }^{2}$, I. Dupčić-Radić ${ }^{2}$, M. Blažina ${ }^{1}$, and S. Orlić ${ }^{1, *}$ \\ ${ }^{1}$ Center for Marine Research, Ruđer Bošković Institute, G. Paliage 5, 52210 Rovinj, Croatia \\ ${ }^{2}$ Institute for Marine and Coastal Research, University of Dubrovnik, Kneza Damjana Jude 12, 20000 Dubrovnik, Croatia \\ *now at: Division of Material Chemistry, Ruđer Bošković Institute, Bijenička 54, 10000 Zagreb, Croatia
}

Correspondence to: M. Najdek (najdek@cim.irb.hr)

Received: 30 October 2013 - Published in Biogeosciences Discuss.: 15 November 2013

Revised: 27 March 2014 - Accepted: 5 April 2014 - Published: 20 May 2014

\begin{abstract}
This paper documents the picoplankton community's response to changes in oceanographic conditions in the period between October 2011 and September 2012 at two stations belonging to the South Adriatic Pit (SAP). The recorded data include the community's abundance, composition, prokaryotic production rates and bacterial metabolic capacity. The sampling period included an intense sea cooling with formation of exceptional, record-breaking dense water. We documented an especially intense winter convection episode that completely diluted the core of Levantine intermediate waters (LIW) in a large area encompassing the SAP's center and its margin. During this convection event the whole picoplankton community had significantly higher abundances with a recorded picoeukaryotic peak at the SAP margin. In the post-convection phase in March, prokaryotic heterotrophic production strongly increased in the entire SAP area (up to 50 times; $456.8 \mathrm{nMC} \mathrm{day}^{-1}$ ). An autotrophic biomass increase (up to 5 times; $4.86 \mu \mathrm{g} \mathrm{L}^{-1}$ ) and a disruption of a close correspondence between prokaryotic heterotrophic biomass production and cell replication rates were observed only in the center of the SAP, which was not under the influence of LIW. At the SAP's margin such an effect was attenuated by LIW, since the waters affected by LIW were characterized by decreased concentrations of dissolved inorganic nitrogen, decreased autotrophic biomasses, and by increased bacterial biomass production balanced with cell replication rates as well as by the domination of Synechococcus among autotrophic picoplankton. The metabolic capacity was lowest in spring when autotrophic biomass largely increased, while the highest levels found in the pre-convection
\end{abstract}

phase (October 2011) suggest that the system was more oligotrophic before than after the convection event. Furthermore, we showed that metabolic capacity is a trait of bacterial community independent of environmental conditions and tightly linked to cell replication and substrate availability. In contrast, the bacterial community composition appears to be strongly influenced by physico-chemical characteristics of waters (e.g., temperature and nutrients) and environmental forcing (e.g., convection and LIW). Our results showed that the two oceanographic phenomena of the Southern Adriatic, strongly relevant for the total production of the Adriatic Sea, winter convection and LIW intrusion, regulate the changes in picoplankton community structure and activities.

\section{Introduction}

The Southern Adriatic includes the deepest part of the Adriatic basin, the South Adriatic Pit (SAP 1243 m). The area above the pit is characterized by a quasi-permanent cyclonic gyre, the South Adriatic Gyre (Gačić et al., 1997). In the winter period, due to convection processes, dense water (Adriatic Dense Water, AdDW) is formed as a mixture of fresher Adriatic and more saline Ionian waters. The convection rarely reaches the bottom layers of the pit, which are mainly under influence of colder and denser water formed in the Northern Adriatic (North Adriatic Dense water; NAdDW; Gačić and Civitarese, 2012). The East Adriatic Current, which partly belongs to the South Adriatic Gyre, brings waters from the Ionian Sea into the Adriatic (Artegiani et al., 1997). 
Depending on the circulation in the Ionian Sea, it transports either high-salinity waters of Levantine origin (LIW) or lower-salinity waters from the Atlantic into the Adriatic (Civitarese et al., 2010). The interaction between the Adriatic and the Mediterranean have been found to resemble the Bimodal Oscillating System (BiOS) that changes the circulation of the North Ionian Gyre (NIG) from cyclonic to anticyclonic and vice versa. This interaction has an important influence on the South Adriatic physical properties (Gačić et al., 2001). Due to the BiOS mechanism thermohaline properties in the Southern Adriatic exhibit a quasi-periodic variability, while nutrients have an opposite phase (Civitarese et al., 2010). LIW, brought by the cyclonic NIG circulation, is characterized by salinity above 38.75 , temperatures higher than $14{ }^{\circ} \mathrm{C}$ and poor nutrient content (Civitarese et al., 1998; Vilibić and Orlić, 2002; Civitarese et al., 2010).

The SA, being highly oligotrophic, is dominated by picophytoplankton community, while microphytoplankton pulses are limited to low-salinity surface layers, deep chlorophyll maximum depths (DCM) and winter convection (Cerino et al., 2012). During a winter convection event (e.g., in 2008) the area of maximal phytoplankton abundance appeared below the euphotic zone (Batistić et al., 2012). Winter convective mixing transports nutrients from the deep reservoir into the upper layer, thus making them available for autotrophs that in spring trigger phytoplankton blooms (Gačić et al., 2002). The intensity of the winter convection and spring blooms influences the downward fluxes of particulate matter to the deepest part of the basin (Boldrin et al., 2002; Turchetto et al., 2012).

Due to the high interannual variability of the winter convection, a marked variability in the phytoplankton abundance and composition was observed (Cerino et al., 2012), together with downward particle fluxes (Turchetto et al., 2012), as well as differences in prokaryotic metabolism in comparison to the years when no convective process occurred (Zaccone et al., 2003; Azzaro et al., 2012).

Metabolic capacity is an important component of bacterial community structure that influences the overall community performance in terms of carbon and nutrient metabolism (Comte and del Giorgio, 2009). Biolog plates for evaluation of the microbial metabolic potential were first used by Garland and Mills (1991). In order to exploit changing sources for growth, both marine (Sala et al., 2006, 2008) and freshwater bacteria (Comte and del Giorgio, 2009, 2010, 2011) express high metabolic plasticity, which is an intrinsic emerging property of bacterial community (Comte et al., 2013).

In our study we explored the link between prokaryotic heterotrophic productions, metabolic capacities (MC) and bacterial community composition (BCC) to document the picoplankton community's response to changes of oceanographic conditions. The investigated period (October 2011September 2012) included an intense sea cooling with the formation of exceptional, record-breaking dense water (Mi- hanović et al., 2013) and open-sea convection in the South Adriatic Pit (Bensi et al., 2013).

\section{Material and methods}

\subsection{Sampling and environmental parameters}

The study was performed at two stations situated on the slope of the SAP, P300 (SAP margin, bottom depth 300-309 m) and P1200 (SAP center, bottom depth 1195-1200 m) (Fig. 1), during five cruises taking place on 3 October 2011, 18 February, 29 March, 30 May and 10 September 2012. The deepest sampling depths at both stations were $20-30 \mathrm{~m}$ above the recorded bottom depth. Temperature $(T)$ and salinity $(S)$ were measured continuously throughout the water column during the downcasts of the SBE25 (SEA-Bird Electronics Inc., USA) CTD probe. Seawater samples for nutrients, chlorophyll $a(\mathrm{Chl} a)$, picoplankton abundance and composition, prokaryotic heterotrophic production (PHP) and metabolic capacities (MC) were taken with $5 \mathrm{~L}$ Niskin bottles at 12 or 15 depths $(0,5,10,20$, ( $35 \mathrm{~m}$ for Chl $a$ in March), 50, $75,100,150,200,300,400,600$ and $800,1000,1200 \mathrm{~m})$ at station P-1200 and 9 depths at station P-300 $(0,5,10,20,50$, $75,100,200$ and $300 \mathrm{~m})$. The samples for nutrients: nitrate $\left(\mathrm{NO}_{3}\right)$, nitrite $\left(\mathrm{NO}_{2}\right)$, phosphate $\left(\mathrm{PO}_{4}\right)$ and silicate $\left(\mathrm{SiO}_{4}\right)$ were frozen $\left(-22^{\circ} \mathrm{C}\right)$ and analyzed in a laboratory according to Strickland and Parsons (1972). Subsamples for ammonia were fixed immediately after collection onboard with $1 \mathrm{~mol} \mathrm{~L}^{-1}$ phenol/EtOH and determined in the laboratory according to Ivančić and Degobbis (1984). The detection limits and reproducibility for nutrients were as follows: nitrate 0.05 and $0.025 \mu \mathrm{mol} \mathrm{L}^{-1}$; nitrite 0.01 and $0.01 \mu \mathrm{mol} \mathrm{L}^{-1}$; ammonia 0.1 and $0.098 \mu \mathrm{mol} \mathrm{L}^{-1}$; silicate 0.1 and $0.06 \mu \mathrm{mol} \mathrm{L}^{-1}$; and phosphate 0.03 and $0.03 \mu \mathrm{mol} \mathrm{L}^{-1}$. Dissolved inorganic nitrogen (DIN) was calculated as the sum of $\mathrm{NO}_{3}, \mathrm{NO}_{2}$ and $\mathrm{NH}_{4}$. Chl $a$ concentrations were determined by filtration of $500 \mathrm{~mL}$ on Whatman GF/F filters. Filters were frozen $\left(-18^{\circ} \mathrm{C}\right)$ and analyzed within a few days by the fluorometric procedure after extraction in $90 \%$ acetone (Holm-Hansen et al., 1965). The detection limit for chlorophyll $a$, considering the filtered volume of water, was $0.01 \mu \mathrm{g} \mathrm{L}^{-1}$.

\subsection{Picoplankton abundance}

Samples for picoplankton counts were preserved on board in $0.5 \%$ glutaraldehyde for $10 \mathrm{~min}$, frozen in liquid nitrogen, and stored at $-80^{\circ} \mathrm{C}$ until analysis. Samples were analyzed on a Partec PAS III (Germany) flow cytometer, equipped with an Argon laser $(488 \mathrm{~nm})$. Instrumental settings were standardized for all parameters using fluorescence polystyrene calibration beads of 1,3 and $10 \mu \mathrm{m}$ diameter.

The different populations of picophytoplankton, namely Synechococcus, Prochlorococcus and picoeukaryotes were distinguished by the red autofluorescence of the chlorophyll content of their cells (FL3) and the cells' forward-angle light 


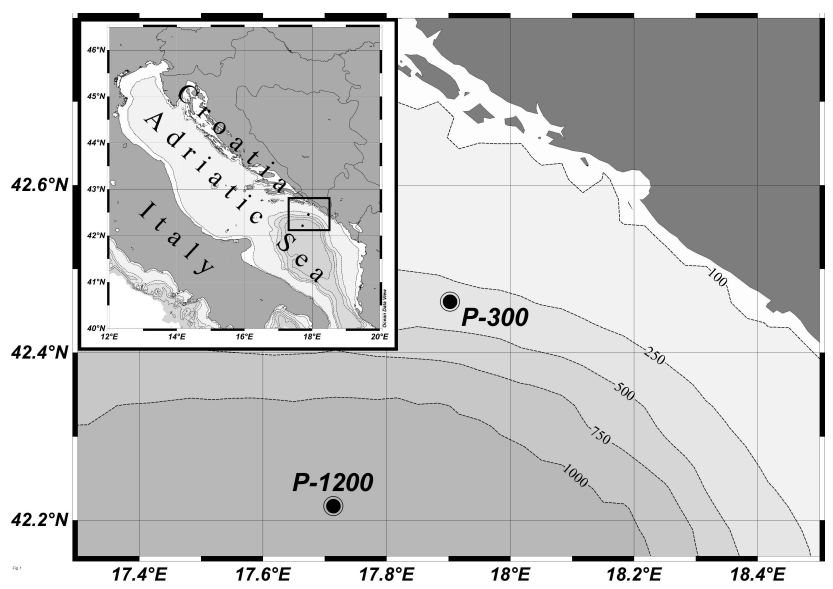

Figure 1. Sampling stations in the Southern Adriatic.

scatter (FSC) as a proxy of their size as well as the orange fluorescence (FL2) of their phycoerythrin-rich cells. The abundances of heterotrophic prokaryotes (HP) were enumerated after staining with the DNA dye, SYBR Green I (Marie et al., 1997).

The final abundance of each group was obtained by true volumetric absolute counting. The precision of the volume measurement is defined by a fixed mechanical design, eliminating errors related to varying bead concentrations usually used.

\subsection{Leucine and thymidine incorporation rates}

The rate of ${ }^{3} \mathrm{H}$-leucine and ${ }^{3} \mathrm{H}$-thymidine incorporation into macromolecules was measured for estimation of prokaryotic heterotrophic production (Smith and Azam, 1992; Fuhrman and Azam, 1982; Kirchman et al., 1985). Triplicates (1.7 mL aliquots) of samples were incubated with $\mathrm{L}-\left[4,5-{ }^{3} \mathrm{H}\right]$ leucine (spec. activity $>100 \mathrm{Ci} \mathrm{mmol} \mathrm{L}^{-1}, 20 \mathrm{nmol} \mathrm{L}^{-1}$ final conc.) or methyl- ${ }^{3} \mathrm{H}$-thymidine (spec. activity $>70 \mathrm{Ci} \mathrm{mmol} \mathrm{L}^{-1}$, $20 \mathrm{nmol} \mathrm{L}^{-1}$ final conc.) in sterile $2.0 \mathrm{~mL}$ microcentrifuge tubes for $2 \mathrm{~h}$ for surface $(0-200 \mathrm{~m})$ and $4 \mathrm{~h}$ for deep waters (400-800 m) (Azzaro et al., 2012; Ruiz-Gonzales et al., 2012) in the dark at in situ temperature. Samples with $100 \%$ TCA added prior to the addition of isotopes served as blanks. The incubations were terminated by adding TCA (conc. $5 \%$ ). Thereafter, samples were centrifuged; supernatant discarded and labeled material was extracted consecutively with cold $5 \%$ TCA, $80 \%$ ethanol and collected by centrifugation. Cellspecific leucine and thymidine incorporation rates were obtained by dividing the average bulk rates per liter by HP abundance.

\subsection{Bacterial community metabolic capacity}

Bacterial carbon substrate utilization profiles, determined with BIOLOG Ecoplates, were used as a proxy of bacterial community metabolic capacity (Comte and del Giorgio,
2009). Ecoplates contain 96 wells with 31 different carbon sources (in triplicates) belonging to amino acids (6), amines (2), esters (1), carbohydrates (7), carboxylic acids (9), polymers (4) and phosphorylated compounds (2) plus a tetrazolium salt, which is reduced to a colored compound by active bacteria (Garland and Mills, 1991). Each well was inoculated with $150 \mu \mathrm{L}$ of unfiltered natural samples. Immediately upon inoculation, the zero time-point absorbance of each plate was read. Changes in color development were measured using microplate reader (Multiscan Ascent, Lab Systems) at $595 \mathrm{~nm}$. The time course of color development was followed for 3-7 days until maximum color development was reached. The overall color development of each plate was expressed as average well color development (AWCD) and computed as $[\Sigma(R-C)] / 93$, where $R$ is the absorbance of each response well, and $C$ is the average of the absorbance of the control wells.

\subsection{Bacterial community composition}

For DGGE analysis, $5 \mathrm{~L}$ of seawater was collected in $0.2 \mu \mathrm{m}$ pore diameter filters (Nuclepore PC) with peristaltic pump. Filters were placed in cryo-vials, filled with $1.8 \mathrm{~mL}$ of lysis buffer $\left(40 \mathrm{mmol} \mathrm{L}^{-1}\right.$ EDTA, $50 \mathrm{mmol} \mathrm{L}^{-1}$ Tris- $\mathrm{HCl}$, $0.75 \mathrm{~mol} \mathrm{~L}^{-1}$ sucrose) and stored at $-80^{\circ} \mathrm{C}$. DNA was extracted as previously described (Boström et al., 2004). Briefly, cells were treated with lysozyme, proteinase $\mathrm{K}$, and sodium dodecyl sulfate followed by phenol-chloroformisoamyl alcohol extraction. Extracted DNA was desalted and treated with concentrated ethanol and $5 \mathrm{M}$ sodium acetate. DNA was diluted in $50 \mathrm{~mL}$ of MQ water. Microbial DNA (1 ng) was used as template for PCR (polymerase chain reaction) amplification of bacterial $16 \mathrm{~S}$ rDNA using the bacterium-specific primer 358f, with a 40 bp GC clamp, and the universal primer $907 \mathrm{r}$. The reaction mixture volumes were $50 \mu \mathrm{mol} \mathrm{L}^{-1}$, containing $200 \mu \mathrm{mol} \mathrm{L}^{-1}$ of each of the deoxynucleoside triphosphate, $0.3 \mu \mathrm{mol} \mathrm{L}^{-1}$ of each of the primers, $1.5 \mathrm{mmol} \mathrm{L}^{-1} \mathrm{MgCl}_{2}, 1 \times \mathrm{PCR}$ buffer and 1 U Taq DNA polymerase (Applied Biosystems). The Dcode universal mutation detection system (Bio-Rad Laboratories) was used for DGGE analysis of the PCR products. A $6 \%$ polyacrylamide gel with a gradient of DNA-denaturant agent was cast by mixing solutions of 30 and $60 \%$ denaturant agent $\left(100 \%\right.$ denaturant agent is $7 \mathrm{~mol} \mathrm{~L}^{-1}$ urea and $40 \%$ deionized formamide). A total of $800 \mathrm{ng}$ of PCR product was loaded for each sample and the gel was run at $100 \mathrm{~V}$ for $16 \mathrm{~h}$ at $60^{\circ} \mathrm{C}$ in $1 \times$ TAE buffer $\left(40 \mathrm{mmol} \mathrm{L}^{-1}\right.$ Tris [pH 7.4], $20 \mathrm{mmol} \mathrm{L}^{-1}$ sodium acetate, $1 \mathrm{mmol} \mathrm{L}^{-1}$ EDTA). Gels were stained with the nucleic acid stain SYBR Gold Safe (Molecular Probes) for $20 \mathrm{~min}$, and rinsed with $1 \times \mathrm{TAE}$ running buffer (Orlić et al., 2013). 


\subsection{Statistical analysis}

According to salinity criteria (Vilibić and Orlić, 2002) two groups of water masses were identified: Levantine Intermediate Waters (LIW; $S>38.75$ ) and South Adriatic Waters (SAW; $S<38.75$ ). Additionally, waters were divided into a productive layer (PL) and a deeper layer (DL) according to a concentration of Chl $a$ above or below the detection limit $\left(0.01 \mu \mathrm{g} \mathrm{L}^{-1}\right)$, respectively. The productive layer refers to a layer of the newly produced (labile and biologically utilizable) carbon; nevertheless, it was produced or brought by mixing. Differences between the waters, layers and stations were tested by two sample $t$ tests, comparison of means from two groups of each parameter. Differences between cruises and stations in each cruise for all parameters were tested by one-way ANOVA. All data were $\log$ or $\log +1$ transformed to ensure compliance with assumptions of ANOVA (Supplement Tables S1 and S2). The results are presented as mean $\pm \mathrm{sd}$.

\section{Results}

\subsection{Environmental conditions}

The presence of LIW was recorded at station P300 during the whole research period (with exception of the February cruise), while in May and September LIW was also detected at offshore station P1200 (Fig. 2). The intense vertical convection occurred in February. It was detected at stations $\mathrm{P} 1200$ and $\mathrm{P} 300$, in the upper $500-600 \mathrm{~m}$ and upper $200 \mathrm{~m}$ layer, respectively. The temperature $(T)$ of the water column at station P1200 became rather uniform, particularly in the layer between 10 and $500 \mathrm{~m}$ with a value of $13.7^{\circ} \mathrm{C}$. Vertical convection that took place in a large cyclonic gyre around the SAP was denoted by lower surface concentration of Chl $a$ in the satellite image (Fig. 3). In March, due to heating, stratification started in a thin surface layer. In October 2011, and May and September 2012 both stations were characterized with deeper thermocline. In February advection of lower salinity $(S)$ and colder waters was observed in the layer below $200 \mathrm{~m}$ at P300. An important drop in $S$ and $T$ that could be ascribed to the arrival of NAdDW occurred in a thin layer (810-850 m) during March at P1200. During May the influence of NAdDW strengthened, causing additional decrease in $S$ and $T$ in a much thicker layer, 800$1200 \mathrm{~m}$ (Fig. 2).

During the convection episode in February, nutrients were generally homogenously distributed throughout the mixed layer, as shown for DIN (Fig. 4). In this layer Chl $a$ was also homogeneously distributed (Fig. 4). During other months nutrient concentrations were lower in the upper $<200$ m layers and higher in the deeper layers. The highest $\mathrm{Chl} a$ values (up to $4.86 \mu \mathrm{g} \mathrm{L}^{-1}$ at $35 \mathrm{~m}$ ) were observed in March, while February and less productive months (May and September

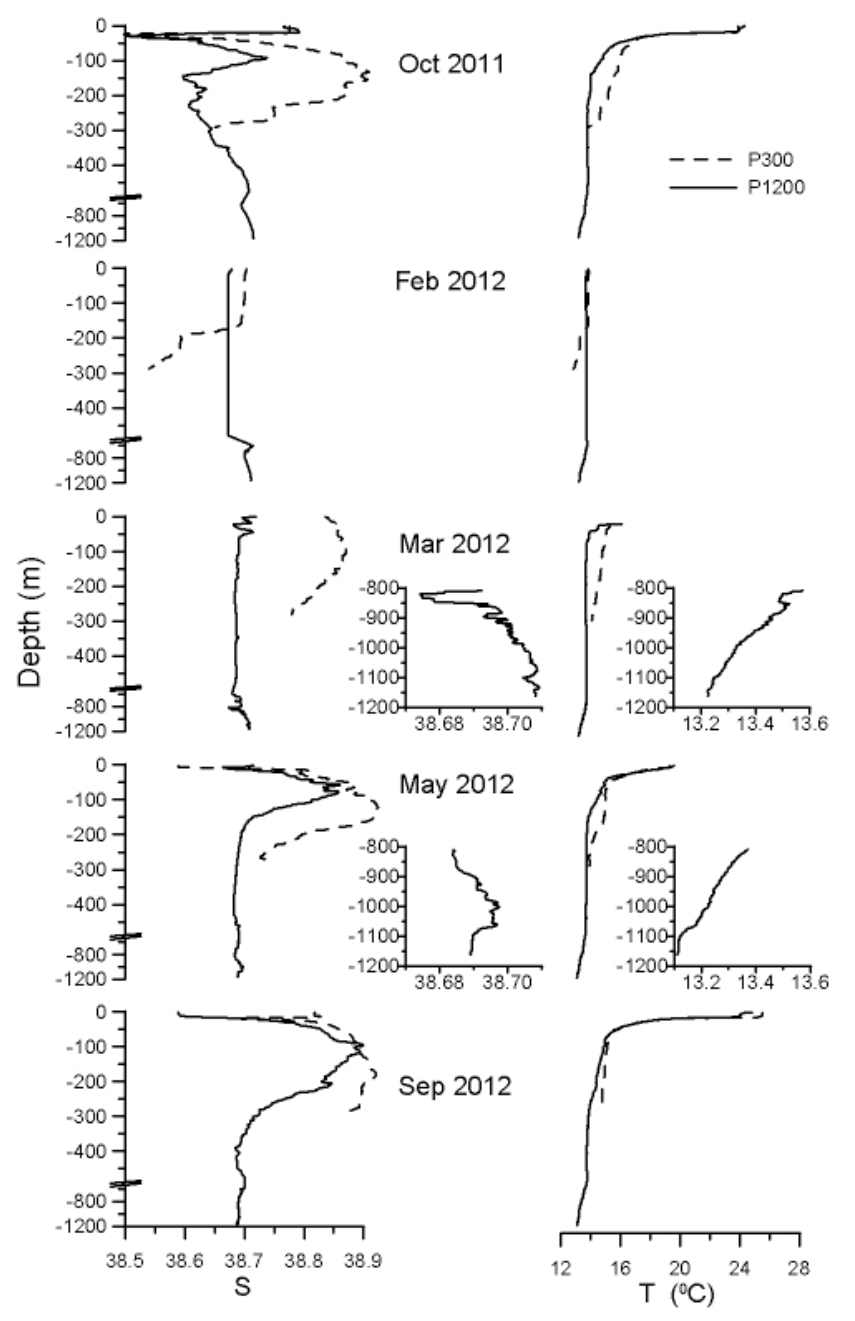

Figure 2. Vertical distribution of salinity $(S)$ and temperature $(T)$ at stations P300 and P1200 during the cruises (3 October 2011, 18 February 2012, 29 March 2012, 30 May 2012, 10 September 2012).

2012 and October 2011) exhibited fairly low values (Fig. 4). A satellite image (Fig. 3) showed that Chl $a$ was enhanced in the surface layer of large areas around the SAP. During all cruises (except in February), a deep Chl $a$ maximum (DCM) was observed at 75-100 $\mathrm{m}$ depth and in that layer the highest abundances of heterotrophic prokaryotes (HP) were observed (Fig. 4).

During the investigated period within the productive layer (Table 1) the waters around stations P1200 and P300 differed significantly in $S$ (Supplement Table S1), caused by varying presence of LIW in October 2011 and March 2012 (Fig. 2; Supplement Table S2). The area affected by the LIW (LIW area; $S: 38.83 \pm 0.04 ; T: 17.6 \pm 4.2^{\circ} \mathrm{C}$ ) was warmer, with significantly lower Chl $a$, DIN (primarily nitrate) and silicate in comparison with non-affected areas (which we name the South Adriatic Waters (SAW) area; $S: 38.65 \pm 0.15 ; T$ : $15.8 \pm 3.3^{\circ} \mathrm{C}$ ). The phosphate in both LIW and SAW areas had similar values (Fig. 5; Supplement Table S1). However, 

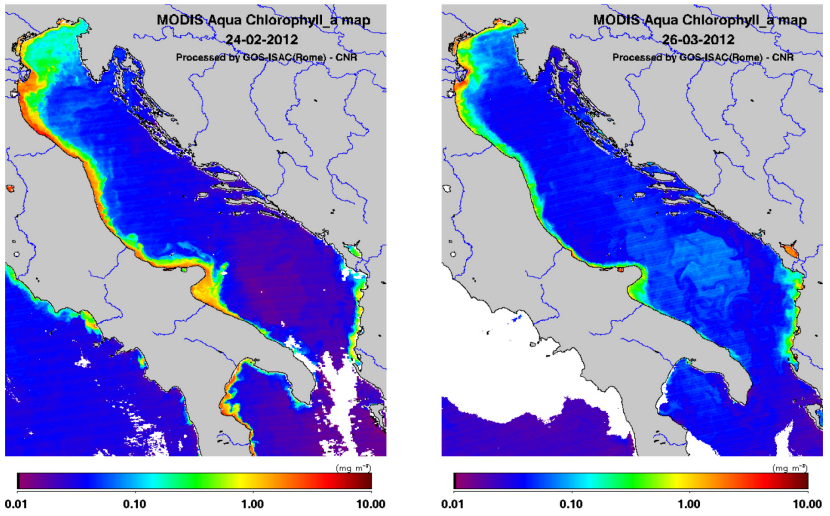

Figure 3. Satellite image (MODIS Aqua Chlorophyll $a$ map, processed by GOS-ISAC (Rome) - CNR) of surface chlorophyll $a$ $\left(\mu \mathrm{g} \mathrm{L}^{-1}\right)$ distribution in the Adriatic Sea on 24 February 2012 and 26 March 2012.

Table 1. Depth of the productive layer (PL) for the respective cruise and station.

\begin{tabular}{lll}
\hline Cruise & Station & PL depth $(\mathrm{m})$ \\
\hline 3 October 2011 & P300 & $0-200$ \\
& P1200 & $0-200$ \\
18 February 2012 & P300 & $0-300$ \\
& P1200 & $0-600$ \\
29 March 2012 & P300 & $0-300$ \\
& P1200 & $0-200$ \\
30 May 2012 & P300 & $0-200$ \\
10 September 2012 & P1200 & $0-150$ \\
& P300 & $0-200$ \\
& P1200 & $0-150$ \\
\hline
\end{tabular}

due to higher concentrations at $\mathrm{P} 300$ during February, waters between the P1200 and P300 were, on average, significantly different in that parameter (Supplement Table S2).

$T$, DIN, silicate and Chl $a$ in the productive layer of both stations were generally homogenously distributed with expressed seasonality. $S$ and $T$ were significantly lower in February $\left(S: 38.62 \pm 0.23, T: 13.7 \pm 0.2{ }^{\circ} \mathrm{C}\right)$, while continuously increasing during March $(S: 38.77 \pm 0.08, T$ : $\left.14.6 \pm 0.7^{\circ} \mathrm{C}\right)$, May $\left(S: 38.76 \pm 0.09, T: 16.6 \pm 2.2^{\circ} \mathrm{C}\right)$ and September $\left(S: 38.78 \pm 0.11, T: 19.6 \pm 4.7^{\circ} \mathrm{C}\right)$. During October 2011, $S$ and $T\left(S: 38.75 \pm 0.08, T: 19.6 \pm 4.4^{\circ} \mathrm{C}\right)$ were similar to values recorded in September 2012. DIN and silicate were higher in February than in other months. The phosphate did not differ significantly between seasons (Fig. 6, Supplement Table S1).

The layer where $\mathrm{Chl} a$ was under detection limit (Chl $a<0.01 \mu \mathrm{g} \mathrm{L}^{-1}$ ) was defined as deeper layer (DL). At both stations in October 2011 DL-considered depths were below $200 \mathrm{~m}$, and in May and September 2012 below 200 and $150 \mathrm{~m}$ at stations $\mathrm{P} 300$ and P1200, respectively. During February and March 2012 DL-considered

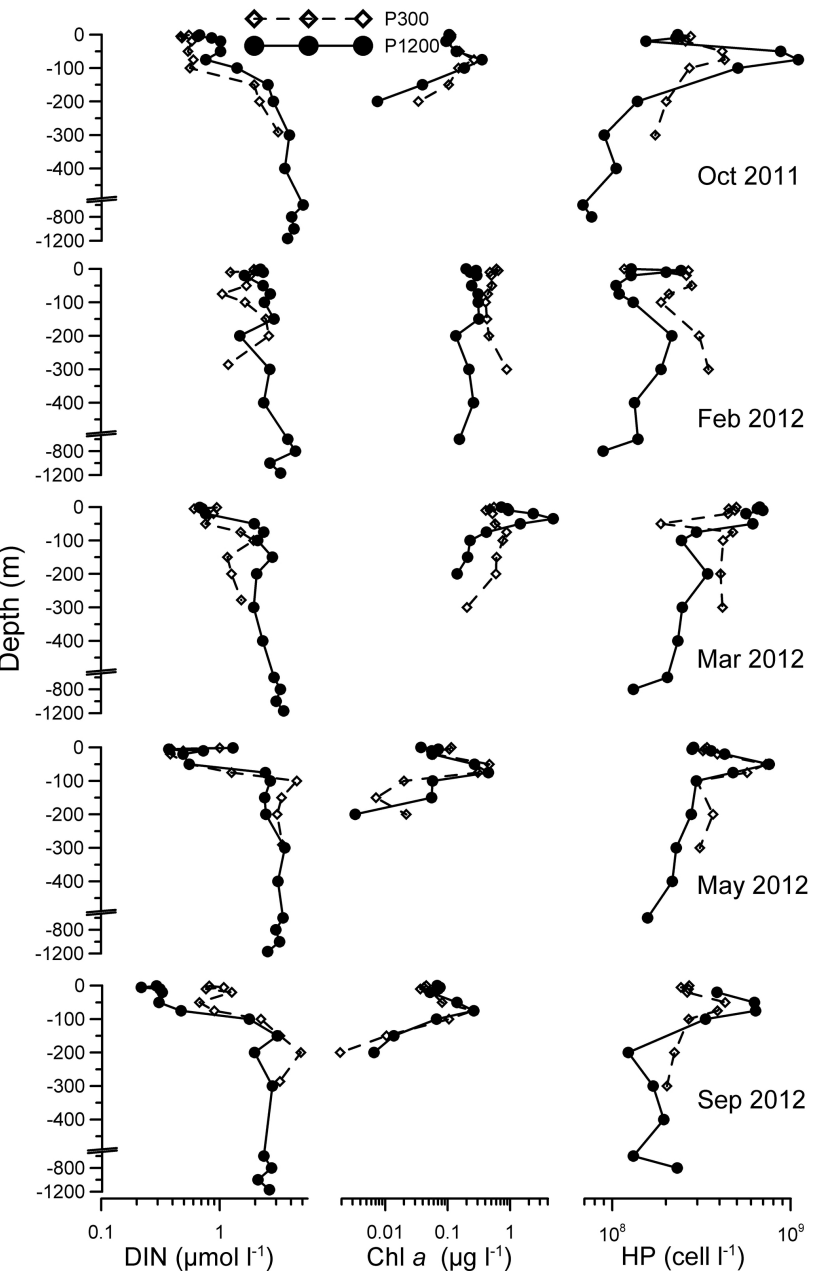

Figure 4. Vertical distribution of dissolved inorganic nitrogen (DIN), chlorophyll $a(\mathrm{Chl} a)$ and heterotrophic prokaryotes abundance (HP) at stations P300 and P1200 during the cruises (3 October 2011, 18 February 2012, 29 March 2012, 30 May 2012, 10 September 2012)

depths were below 600 and $200 \mathrm{~m}$ at P1200, respectively. In general, the deeper layer was significantly colder (DL: $13.7 \pm 0.3^{\circ} \mathrm{C}<\mathrm{PL}: 16.7 \pm 3.8^{\circ} \mathrm{C}$ ) and richer in DIN, silicate and phosphate than waters in the productive layer (Fig. 6, Supplement Table S1). On the seasonal basis the deeper layer differed in DIN, being the highest in October 2011.

\subsection{Picoplankton abundances}

Within the productive layer, heterotrophic prokaryotes (HP) had the lowest abundances in February and the highest in March while other months were similar to each other. HP abundances were significantly higher in the productive $\left(3.6 \pm 1.9 \times 10^{8}\right.$ cell L $\left.^{-1}\right)$ than in the deeper layer $\left(1.7 \pm 0.7 \times 10^{8}\right.$ cell $\left.\mathrm{L}^{-1}\right)$. In the deeper layer, no seasonality in HP was observed (Supplement Table S1). HP significantly 
Table 2. Standardized correlation coefficients $(r)$ for correlations between abundances of picoplankton, bulk cell specific prokaryotic heterotrophic production and environmental parameters. The number of data is given in parenthesis. All data were $\log$ or $\log (x+1) \operatorname{transformed}$ and significant correlations (in bold) are at ${ }^{\mathrm{a}} p<0.05,{ }^{\mathrm{b}} p<0.001 . \mathrm{pEu}-$ picoeukaryotes, SYN - Synechococcus, Pro - Prochlorococcus, $\mathrm{HP}$ - heterotrophic prokaryotes, bulk and cell-specific prokaryotic rates for leucine (Leu, sLeu) and thymidine (TdR, sTdR) incorporation.

\begin{tabular}{|c|c|c|c|c|c|c|c|c|c|}
\hline & $\mathrm{pEu}$ & SYN & Pro & HB & Chl $a$ & Leu & sLeu & $\mathrm{TdR}$ & sTdR \\
\hline Temperature $T$ & $\begin{array}{r}-\mathbf{0 . 5 1 8}^{\mathrm{b}} \\
(68)\end{array}$ & $\begin{array}{r}\mathbf{0 . 3 5 4} \\
(68)\end{array}$ & $\begin{array}{r}0.465 \\
(17)\end{array}$ & $\begin{array}{l}0.177 \\
(101)\end{array}$ & $\begin{array}{r}-0.444^{b} \\
(84)\end{array}$ & $\begin{array}{r}\mathbf{0 . 3 1 7 ^ { b }} \\
(80)\end{array}$ & $\begin{array}{r}\mathbf{0 . 3 2 8}^{\mathrm{b}} \\
(80)\end{array}$ & $\begin{array}{l}0.057 \\
(101)\end{array}$ & $\begin{array}{l}0.094 \\
(101)\end{array}$ \\
\hline Salinity $S$ & $\begin{array}{r}-0.011 \\
(68)\end{array}$ & $\begin{array}{r}0.159 \\
(68)\end{array}$ & $\begin{array}{r}0.278 \\
(17)\end{array}$ & $\begin{array}{l}0.159 \\
(101)\end{array}$ & $\begin{array}{r}-0.060 \\
(84)\end{array}$ & $\begin{array}{r}\mathbf{0 . 3 0 0}^{\mathrm{b}} \\
(80)\end{array}$ & $\begin{array}{r}\mathbf{0 . 3 0 9}^{\mathrm{b}} \\
(80)\end{array}$ & $\begin{array}{l}0.116 \\
(101)\end{array}$ & $\begin{array}{l}0.100 \\
(101)\end{array}$ \\
\hline $\begin{array}{l}\text { Dissolved inorganic } \\
\text { nitrogen DIN }\end{array}$ & $\begin{array}{r}0.277^{\mathrm{a}} \\
(68)\end{array}$ & $\begin{array}{r}-0.499^{b} \\
(68)\end{array}$ & $\begin{array}{r}-0.661^{b} \\
(17)\end{array}$ & $\begin{array}{r}-\mathbf{0 . 5 4 3} \\
(101)\end{array}$ & $\begin{array}{r}0.079 \\
(84)\end{array}$ & $\begin{array}{r}-\mathbf{0 . 3 7 2} \\
(80)\end{array}$ & $\begin{array}{r}-\mathbf{0 . 2 2 4 ^ { \mathrm { a } }} \\
(80)\end{array}$ & $\begin{array}{r}-0.131 \\
(101)\end{array}$ & $\begin{array}{r}-0.030 \\
(101)\end{array}$ \\
\hline Nitrate $\mathrm{NO}_{3}$ & $\begin{array}{r}\mathbf{0 . 3 6 3} \\
(68)\end{array}$ & $\begin{array}{r}-\mathbf{0 . 5 3 4} \\
(68)\end{array}$ & $\begin{array}{r}-\mathbf{0 . 5 9 0} \\
(17)\end{array}$ & $\begin{array}{r}-\mathbf{0 . 5 7 7} \\
(101)\end{array}$ & $\begin{array}{r}0.103 \\
(84)\end{array}$ & $\begin{array}{r}-\mathbf{0 . 3 7 3} \\
(80)\end{array}$ & $\begin{array}{r}-0.218 \\
(80)\end{array}$ & $\begin{array}{r}-0.130 \\
(101)\end{array}$ & $\begin{array}{r}-0.018 \\
(101)\end{array}$ \\
\hline Nitrite $\mathrm{NO}_{2}$ & $\begin{array}{r}\mathbf{0 . 5 5 2 ^ { b }} \\
(68)\end{array}$ & $\begin{array}{r}-0.167 \\
(68)\end{array}$ & $\begin{array}{r}\mathbf{0 . 7 1 1}{ }^{b} \\
(17)\end{array}$ & $\begin{array}{l}0.128 \\
(101)\end{array}$ & $\begin{array}{r}\mathbf{0 . 3 9 3}^{\mathrm{b}} \\
(84)\end{array}$ & $\begin{array}{r}-0.056 \\
(80)\end{array}$ & $\begin{array}{r}-0.151 \\
(80)\end{array}$ & $\begin{array}{l}0.016 \\
(101)\end{array}$ & $\begin{array}{r}-0.077 \\
(101)\end{array}$ \\
\hline Ammonia $\mathrm{NH}_{4}$ & $\begin{array}{r}-0.395^{a} \\
(68)\end{array}$ & $\begin{array}{r}0.163 \\
(68)\end{array}$ & $\begin{array}{r}-0.446 \\
(17)\end{array}$ & $\begin{array}{l}0.016 \\
(101)\end{array}$ & $\begin{array}{r}-0.294^{b} \\
(84)\end{array}$ & $\begin{array}{r}-0.110 \\
(80)\end{array}$ & $\begin{array}{r}-0.075 \\
(80)\end{array}$ & $\begin{array}{r}-0.094 \\
(101)\end{array}$ & $\begin{array}{r}-0.078 \\
(101)\end{array}$ \\
\hline Phosphate $\mathrm{PO}_{4}$ & $\begin{array}{r}0.143 \\
(68)\end{array}$ & $\begin{array}{r}0.01 \\
(68)\end{array}$ & $\begin{array}{r}-0.384 \\
(17)\end{array}$ & $\begin{array}{r}-\mathbf{0 . 2 9 8}^{\mathrm{a}} \\
(101)\end{array}$ & $\begin{array}{r}-0.004 \\
(84)\end{array}$ & $\begin{array}{r}-0.074 \\
(80)\end{array}$ & $\begin{array}{r}0.016 \\
(80)\end{array}$ & $\begin{array}{r}-0.014 \\
(101)\end{array}$ & $\begin{array}{r}0.086 \\
(101)\end{array}$ \\
\hline Silicate $\mathrm{SiO}_{4}$ & $\begin{array}{r}0.059 \\
(68)\end{array}$ & $\begin{array}{r}-\mathbf{0 . 3 2 8}^{\mathrm{a}} \\
(68)\end{array}$ & $\begin{array}{r}-0.397 \\
(17)\end{array}$ & $\begin{array}{r}-\mathbf{0 . 7 2 0} 0^{b} \\
(101)\end{array}$ & $\begin{array}{r}-\mathbf{0 . 2 5 3}^{\mathrm{b}} \\
(84)\end{array}$ & $\begin{array}{r}-\mathbf{0 . 6 5 0} 0^{b} \\
(80)\end{array}$ & $\begin{array}{r}-\mathbf{0 . 4 6 7} \\
(80)\end{array}$ & $\begin{array}{r}-\mathbf{0 . 3 6 8}^{\mathrm{b}} \\
(101)\end{array}$ & $\begin{array}{r}-\mathbf{0 . 2 0 7 ^ { a }} \\
(101)\end{array}$ \\
\hline $\begin{array}{l}\text { Chlorophyll } a \\
(\text { Chl } a)\end{array}$ & $\begin{array}{r}\mathbf{0 . 4 9 5} \\
(68)\end{array}$ & $\begin{array}{r}0.023 \\
(68)\end{array}$ & $\begin{array}{r}0.438 \\
(17)\end{array}$ & $\begin{array}{r}0.291^{b} \\
(84)\end{array}$ & - & $\begin{array}{r}0.238 \\
(68)\end{array}$ & $\begin{array}{r}0.105 \\
(68)\end{array}$ & $\begin{array}{r}\mathbf{0 . 2 9 4} \\
(84)\end{array}$ & $\begin{array}{r}0.129 \\
(84)\end{array}$ \\
\hline $\begin{array}{l}\text { Substrate utilization } \\
\text { (AWCD) }\end{array}$ & $\begin{array}{l}- \\
-\end{array}$ & $\begin{array}{l}- \\
-\end{array}$ & $\begin{array}{l}- \\
-\end{array}$ & $\begin{array}{r}-0.011 \\
(101)\end{array}$ & $\begin{array}{r}-0.267^{a} \\
(84)\end{array}$ & $\begin{array}{r}-0.206 \\
(80)\end{array}$ & $\begin{array}{r}-0.196 \\
(80)\end{array}$ & $\begin{array}{r}-\mathbf{0 . 3 2 3}^{\mathrm{b}} \\
(101)\end{array}$ & $\begin{array}{r}-\mathbf{0 . 3 7 6}^{\mathrm{b}} \\
(101)\end{array}$ \\
\hline
\end{tabular}

and positively correlated with $\mathrm{Chl} a$, and negatively with DIN, $\mathrm{PO}_{4}$ and $\mathrm{SiO}_{4}$ (Table 2). Negative correlations of $\mathrm{HP}$ with $\mathrm{DIN}, \mathrm{PO}_{4}$ and $\mathrm{SiO}_{4}$ were probably due to prevailing different processes in the productive and deeper layers, in other words, nutrient utilization in the productive (low nutrients and high HP) and nutrient regeneration and accumulation in the deeper layer (high nutrients and low HP).

The highest abundance of Synechococcus was found in October 2011. During 2012 Synechococcus abundances increased from February to September (Fig. 6). Prochlorococcus appeared in May and reached the highest abundances in September (Fig. 6). In October 2011 Prochlorococcus abundances were also very high, varying in narrower range than in September 2012 (Fig. 6). During October 2011, and May and September 2012 the depths of Synechococcus and Prochlorococcus maxima corresponded closely to and below DCM, respectively. In October 2011 picoeukaryotes had the lowest abundances, while the highest one was recorded in February (Fig. 6). The whole picoplankton community had significantly higher abundances at P300 during February (Supplement Table S2).

Synechococcus and Prochlorococcus were more abundant in LIW than in SAW, while for picoeukaryotes and heterotrophic prokaryotes more uniform distribution was observed (Fig. 5, Supplement Table S1). Synechococcus and Prochlorococcus were significantly negatively correlated with DIN, while picoeukaryotes had significant positive correlation with DIN. Significant positive correlations were also observed between $\mathrm{NO}_{2}$ and picoeukaryotes, and $\mathrm{NO}_{2}$ and Prochlorococcus (Table 2).

\subsection{Leucine and thymidine incorporation rates}

Bulk and cell-specific incorporation rates of leucine (Leu) and thymidine (TdR) varied largely throughout the year in the productive layer (Supplement Table S1), being the lowest in February (Fig. 7). During March both rates increased extremely and significant differences in cell-specific Leu and L/T ratios between stations were observed (Supplement Table S2). Namely, around P300 bulk and cell-specific Leu $(49.7 \pm 28.6$ pmol Leu L ${ }^{-1} \mathrm{~h}^{-1} ; 124.6 \pm 72.0 \mathrm{zmol}^{\mathrm{Leu}} \mathrm{cell}^{-1} \mathrm{~h}^{-1}$ ) were combined with moderate $\mathrm{TdR}\left(5.1 \pm 2.9 \mathrm{pmol} \mathrm{TdR} \mathrm{L}^{-1} \mathrm{~h}^{-1}\right.$; $13.9 \pm 11.0$ zmol TdR cell ${ }^{-1} \mathrm{~h}^{-1}$ ), giving higher $\mathrm{L} / \mathrm{T}$ ratios (24.6 \pm 43.9$)$, and being extremely high (140.6) at DCM depth $(75 \mathrm{~m})$. In contrast, bulk and cell-specific $\operatorname{TdR}\left(16.6 \pm 20.4 \mathrm{pmol} \mathrm{TdR} \mathrm{L}^{-1} \mathrm{~h}^{-1} ; 32.3 \pm 34.0 \mathrm{zmol} \mathrm{TdR}\right.$ 

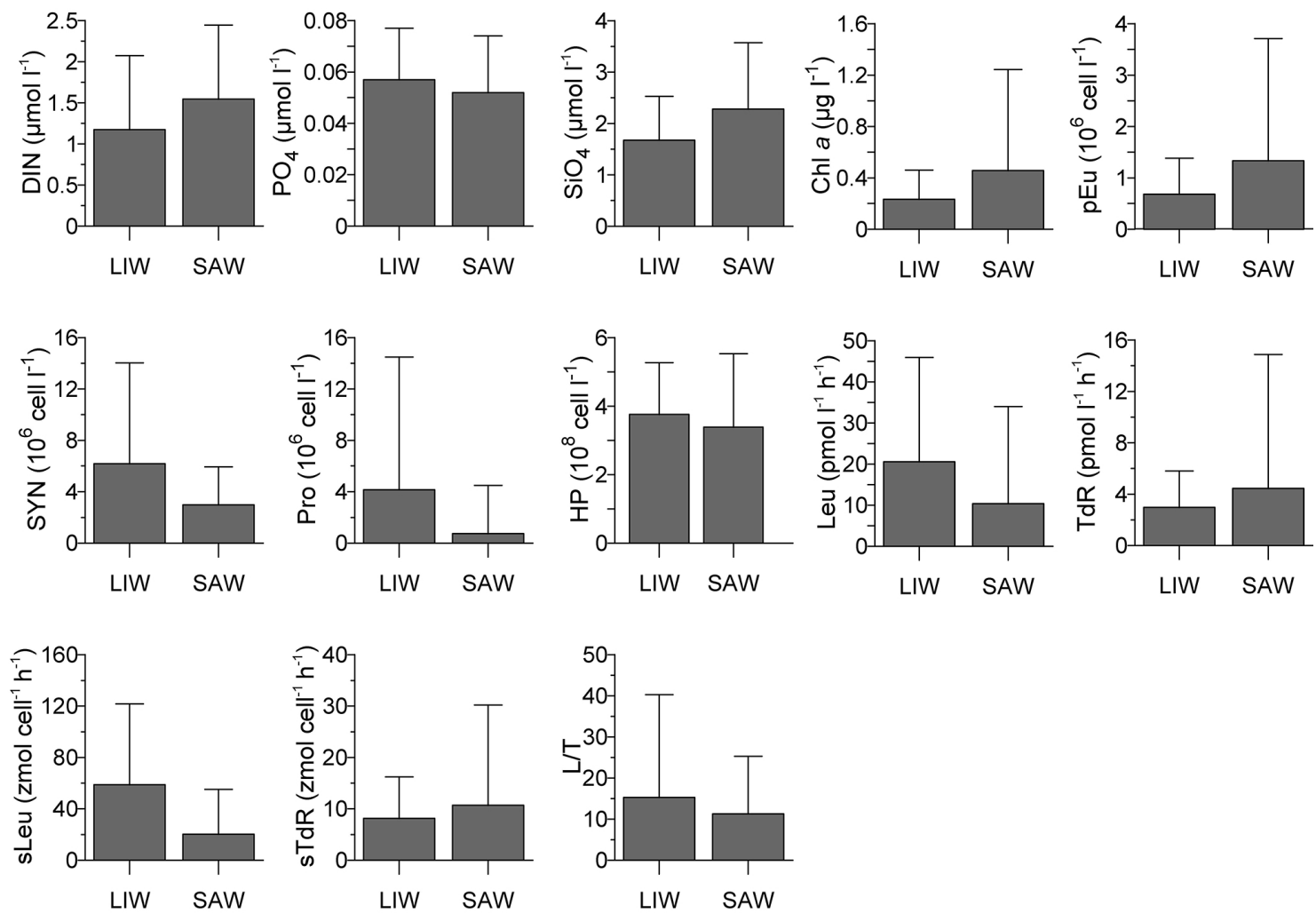

Figure 5. Dissolved inorganic nitrogen (DIN), phosphate $\left(\mathrm{PO}_{4}\right)$, silicate $\left(\mathrm{SiO}_{4}\right)$, chlorophyll $a(\mathrm{Chl} a)$, abundances of picoeukaryotes (pEu), Synechococcus (SYN), Prochlorococcus (Pro), heterotrophic prokaryotes (HP), bulk and cell-specific prokaryotic heterotrophic rates for leucine (Leu, sLeu) and thymidine (TdR, sTdR) incorporation and their ratios (L/T) in Levantine intermediate water (LIW) affected and non-affected waters, Southern Adriatic waters (SAW) in the productive layer.
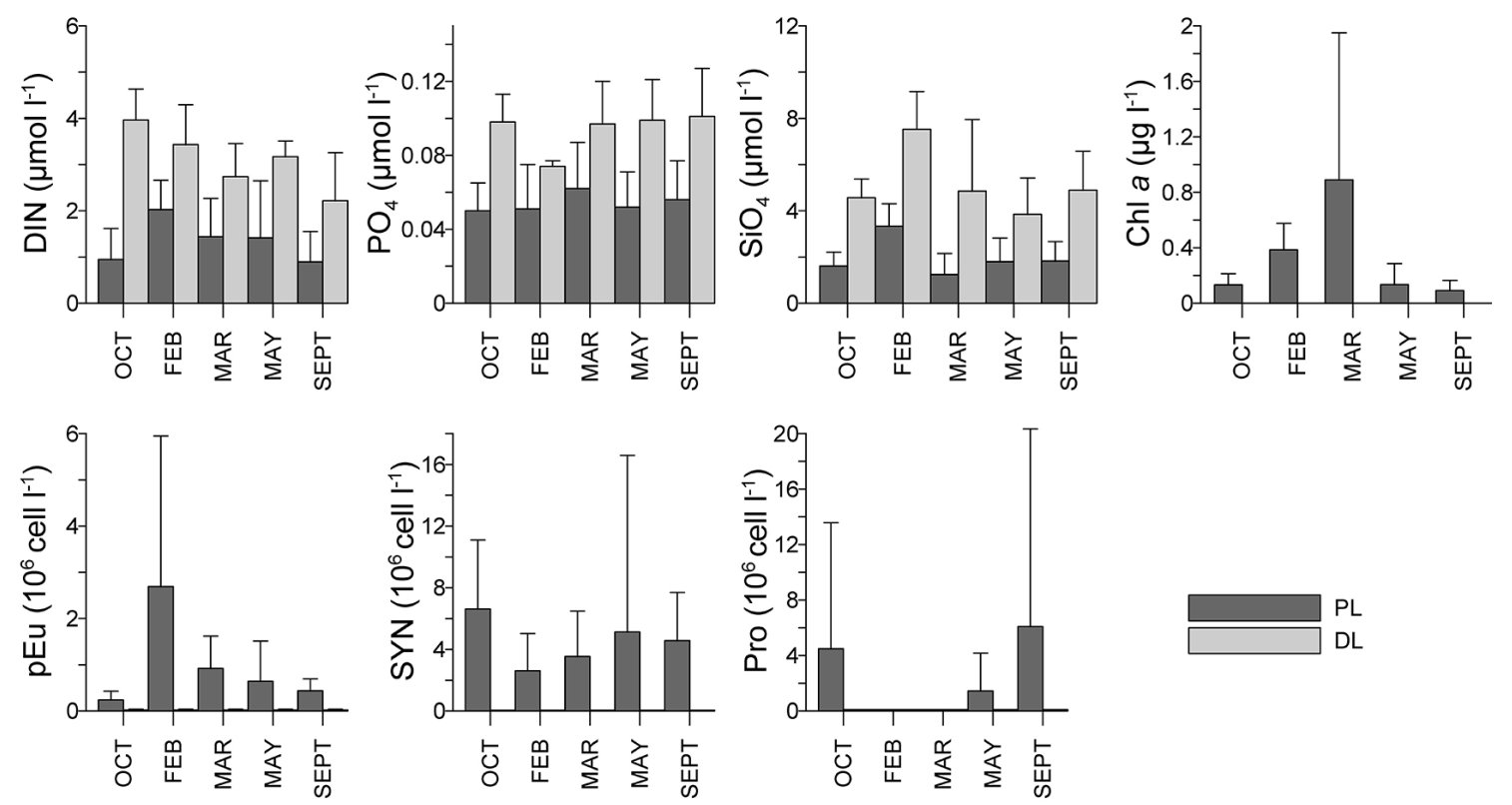

Figure 6. Dissolved inorganic nitrogen (DIN), phosphate $\left(\mathrm{PO}_{4}\right)$, silicate $\left(\mathrm{SiO}_{4}\right)$, chlorophyll $a(\mathrm{Chl} a)$, abundances of picoeukaryotes $(\mathrm{pEu})$, Synechococcus (SYN) and Prochlorococcus (Pro) in productive (PL) and deeper layers (DL) during the cruises (3 October 2011, 18 February 2012, 29 March 2012, 30 May 2012, 10 September 2012). 

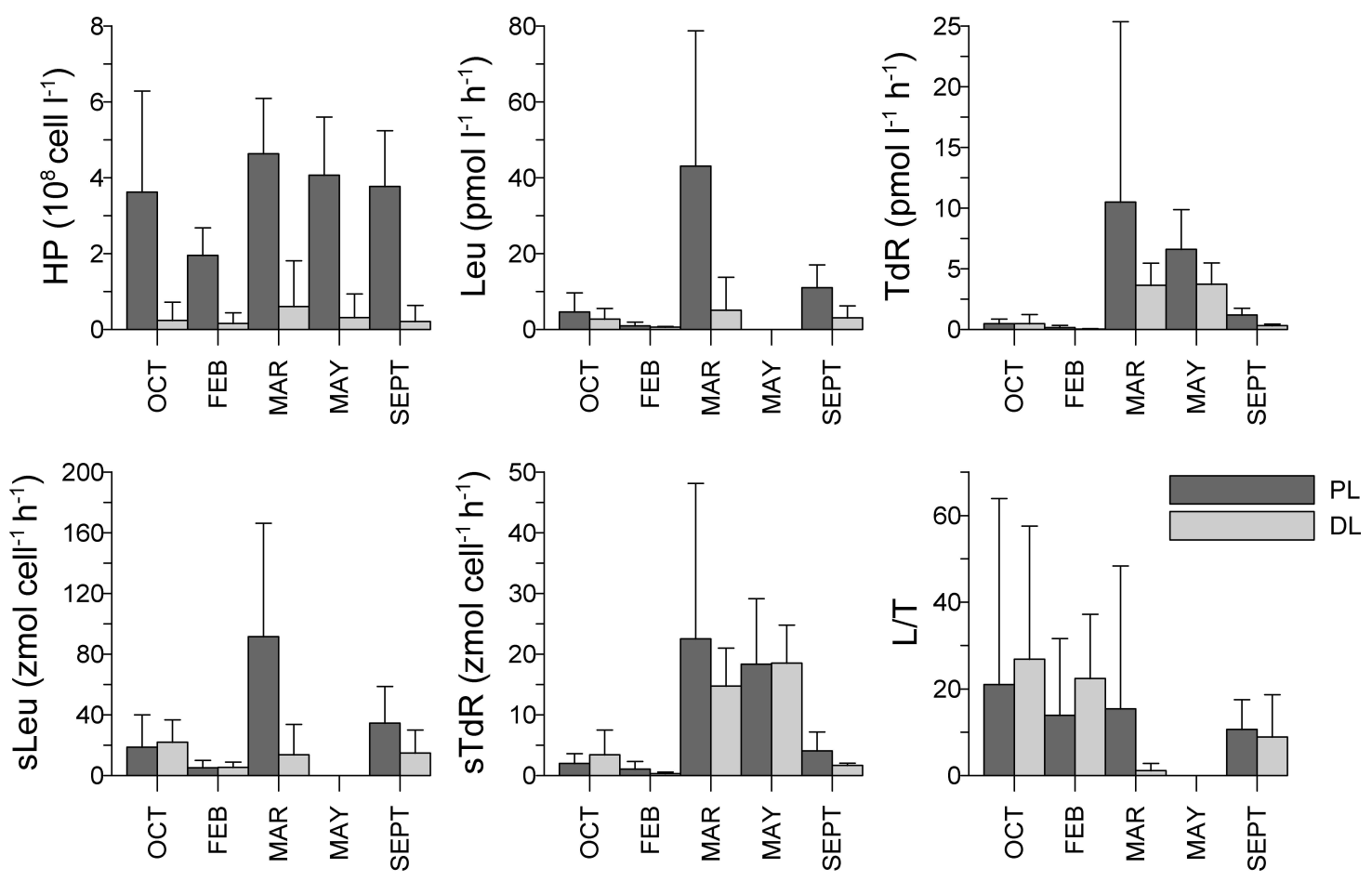

Figure 7. Heterotrophic prokaryotes (HP), and bulk and cell-specific prokaryotic heterotrophic rates for leucine (Leu, sLeu) and thymidine (TdR, sTdR) incorporation and their ratios (L/T) in productive (PL) and deeper layers (DL) during the cruises (3 October 2011, 18 February 2012, 29 March 2012, 30 May 2012, 10 September 2012).

cell $^{-1} \mathrm{~h}^{-1}$ ) at station P1200 were much higher and combined with lower Leu $\left(35.6 \pm 43.1\right.$ pmol Leu L $\mathrm{L}^{-1} \mathrm{~h}^{-1}$; $54.6 \pm 62.4 \mathrm{zmol} \mathrm{Leu} \mathrm{cell}^{-1} \mathrm{~h}^{-1}$ ), giving a lower $\mathrm{L} / \mathrm{T}$ ratio (5.1 \pm 6.8$)$. However, when the $\mathrm{L} / \mathrm{T}$ ratio was calculated only for the layer between 20 and $100 \mathrm{~m}$, where the highest Chl $a$ values were measured, calculated values were extremely low $(0.2 \pm 0.2)$. In May bulk and cell-specific TdR were still high, while in September, both the rates and differences between stations decreased (Fig. 7, Supplement Table S2). During October 2011 both rates were lower and L/T ratios higher than in September 2012 (Fig. 7). In the deeper layer only bulk and cell-specific TdR largely varied seasonally (Supplement Table S1), being very similar in March and May and much higher from the rates determined in September and October 2011 (Fig. 7).

The bulk Leu and TdR significantly and positively correlated with HP abundances through the entire water column. Also both rates significantly and positively correlated with $\mathrm{Chl} a$ in the productive layer. Bulk and cell-specific Leu significantly and positively correlated with $T$ and $S$, while bulk Leu negatively correlated with DIN (Table 2). Bulk and cellspecific Leu were significantly higher in LIW than in SAW. Also bulk Leu was higher in the productive than in the deeper layer (Supplement Table S1).

\subsection{Bacterial community composition}

Cluster analysis of DGGE gel generally separated bacterial communities sampled in productive from those sampled in the deeper layer (Fig. 8). Bacterial communities from the productive layer formed three subclusters, the first of which contained mostly communities from P300, the second and the third from P1200. Bacterial communities from the deeper layer formed two subclusters: the first grouped communities from February, March and September, and the second communities from October 2011. Bacterial communities sampled in March at P1200 (10 m) remained unclustered. DGGE banding patterns for all samples and separately for the productive and deeper layers were analyzed by principal component analysis (PCA). Then the resulting scores of principal components (PC1 and PC2) were analyzed for correlations with environmental parameters, prokaryotic productions and substrate utilization data. The analysis showed that only PC1 scores of DGGE banding patterns of bacterial communities sampled in the productive layer $(28.3 \%$ of variability) significantly correlated with DIN ( $p=0.004)$ and $T(p=0.037)$. Also, only PC1 scores of DGGE banding patterns of bacterial communities sampled in the deeper layer $(28.6 \%$ of variability) significantly correlated with silicate $(p=0.037)$ and phosphate $(p=0.05)$. 


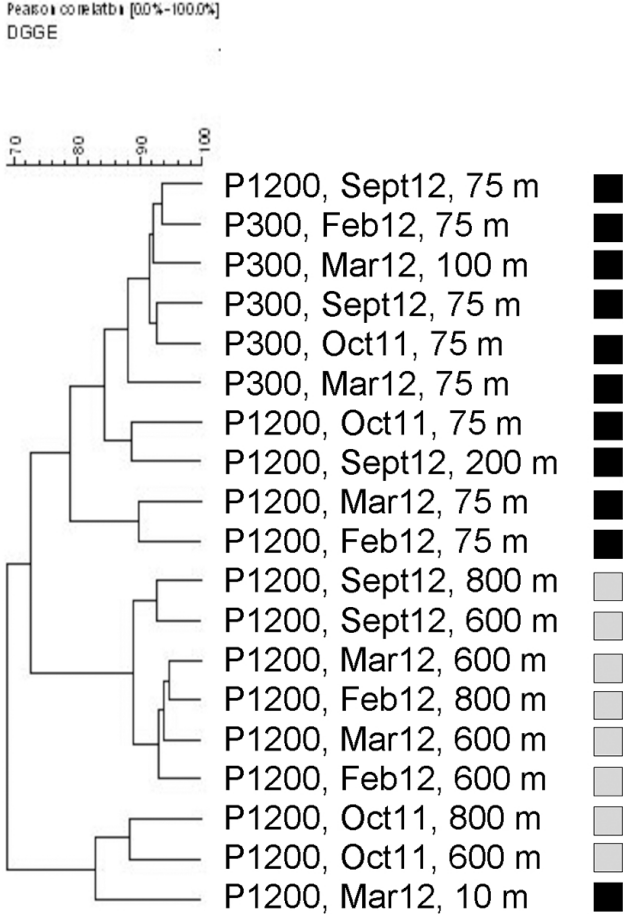

Figure 8. Cluster analysis dendrogram of DGGE banding pattern (Gel Compare, v. 4.1, Applied Maths, Kortrijk, Belgium) performed calculating the Pearson correlation similarity coefficient for bacterial communities sampled in the productive and deeper layers (October 2011-September 2012).

\subsection{Utilization of substrates (metabolic capacity of heterotrophic bacteria)}

Average utilization of substrates (AWCD) showed no significant differences between stations, the productive and deeper layers, or LIW and SAW (Supplement Table S1). During the year, similar variations of AWCD were observed in the productive and deeper layers (Fig. 9a). The variations were more pronounced in the productive layer (Supplement Table S1), with maximum in October 2011 and minimum in March, while during February, May and September AWCD was similar.

In the productive layer, the highest utilization of carbohydrates and carboxylic acids were observed in March and September and the lowest in May and March, respectively. Polymers and amines were mostly utilized in May, although the difference with other months was not significant. The uniform utilization through the seasons was observed for amino acids and phosphorylated compounds (Fig. 9b). Between two stations differences in percent utilization of carbohydrates and amines observed in March became enlarged and significant in May. In October 2011 and September 2012 important differences were observed in amino acids and carbohydrates utilization, respectively (Fig. 10a, Supplement Table S2).

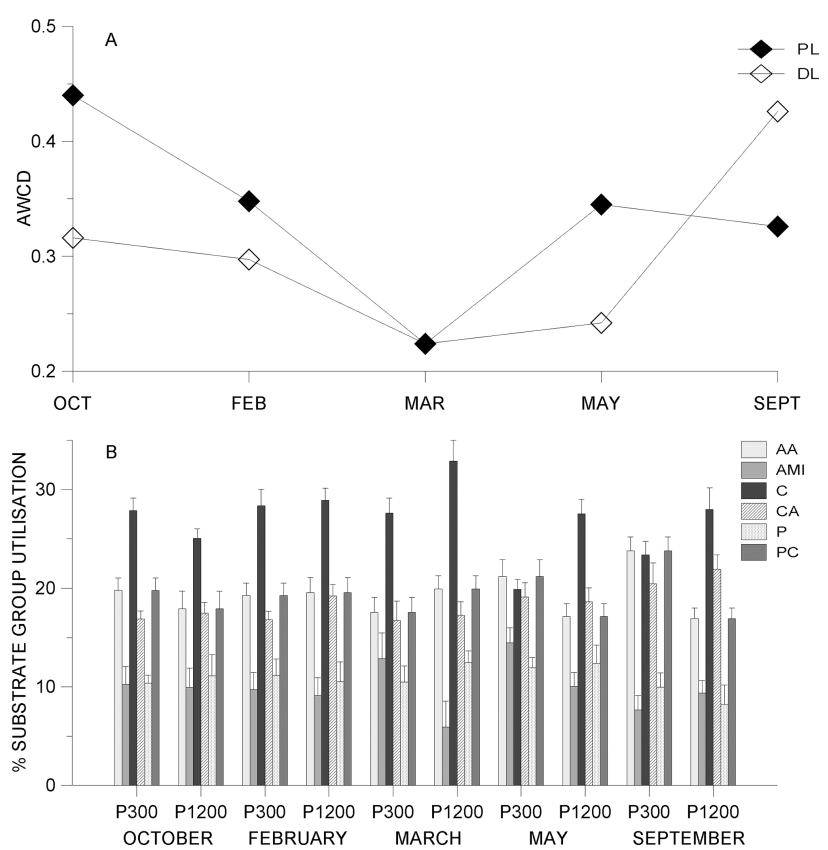

Figure 9. Changes of MC (mean AWCD) in the productive and deeper layers (A); percentage utilization of substrate groups (AA amino acids, AMI - amines, $\mathrm{C}$ - carbohydrates, CA - carboxylic acids, $\mathrm{P}$ - polymers, $\mathrm{PC}$ - phosphorylated compounds) at stations P1200 and P300 (B) during the cruises (3 October 2011, 18 February 2012, 29 March 2012, 30 May 2012 and 10 September 2012).

In the deeper layer differences were observed only in the percent utilization of amino acids, being significantly higher in February in comparison to March and May (Fig. 10b). The pattern of utilization of other groups of substrates, primarily carbohydrates and polymers, was similar to that in the productive layer. In general, the productive layer differed from the deeper layer only in utilization of phosphorylated compounds ( $\mathrm{PL}<\mathrm{DL})$.

AWCD was significantly negatively correlated to bulk and cell-specific TdR uptake rates and positively to $\mathrm{L} / \mathrm{T}$ ratio. In the productive layer AWCD also negatively correlated with Chl $a$ (Table 2). Significance of this relation derived primarily from relationship between carbohydrates and Chl $a(r=-0.329, p=0.017)$ and carboxylic acids and Chl $a$ $(r=-0.299, p=0.031)$.

\section{Discussion}

The picoplankton community of the Southern Adriatic offshore waters during the investigated period was strongly affected by two important oceanographic phenomena taking place in the region; an especially intense winter convection episode in February followed by an outbreak of the new production in March, and intrusions of highly saline and nutrient-poor LIW. 

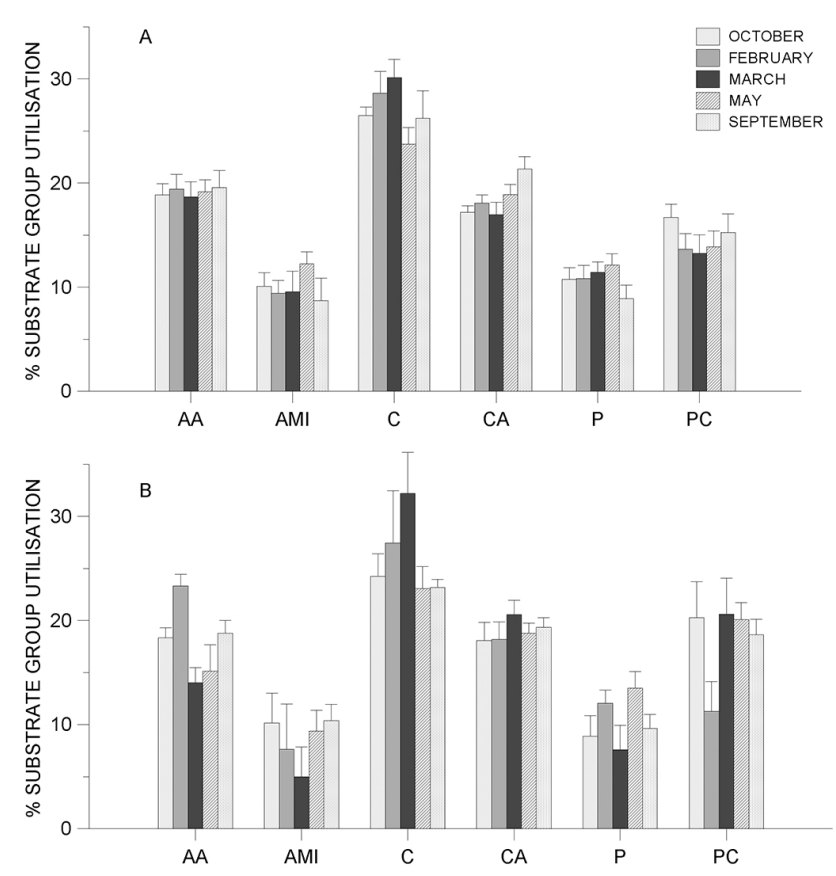

Figure 10. Changes in percentage utilization of substrate groups (AA - amino acids, AMI - amines, C - carbohydrates, CA - carboxylic acids, $\mathrm{P}$ - polymers, $\mathrm{PC}$ - phosphorylated compounds) in the productive layer (A); and deeper layers (B) during the cruises (3 October 2011, 18 February 2012, 29 March 2012, 30 May 2012 and 10 September 2012).

Due to variations in the winter climatic conditions the intensity of open-sea convection and vertical mixing in the area varies strongly on a year-to-year basis (Gačić et al., 2002; Civitarese et al., 2005). February 2012 was characterized by a convection event that homogenized thermohaline properties above the SAP, including its marginal part around station P300. It was presumably induced by a long-lasting Bora episode ( $\sim 3$ weeks), blowing occasionally with hurricane force. Due to extreme cooling during that Bora event, some of the densest water ever measured in the Adriatic Sea $\left(\sigma_{t}>30\right)$ was documented (Mihanović et al., 2013). Since we did not detect LIW during February, we hypothesize that intensive mixing diluted the LIW core residing in the SAP during fall and probably winter 2011. A similar convection episode was recorded in the same area in February 2008, but during that event vertical mixing was less intensive, and LIW remained unperturbed in the intermediate layers (Batistić et al., 2012).

Vertical mixing brought dissolved inorganic nutrients into the upper layer, largely extending the productive layer of the SAP where the occurrence of picoeukaryotes and Synechococcus was documented down to $400 \mathrm{~m}$ and $600 \mathrm{~m}$, respectively. Occurrence of autotrophs in deep layers could be linked to convection or to downslope transport facilitated by NAdDW (Vilibić and Šantić, 2008). The abundances of autotrophs in winter 2012 were lower than previously reported
(Azzaro et al., 2012; Batistić et al., 2012) plausibly ascribable to a much lower amount of available DIN. Generally, lower salinity and nutrient content in winter 2012 suggested involvement of several combined processes that most probably contributed to the dilution of the South Adriatic Basin in 2012.

Although in winter 2011/2012 the eastern coastal zone was under strong impact of LIW (Mihanović et al., 2013), the amount of LIW was obviously not large enough to induce a significant rise of salinity values in the entire water column in the SAP. Thus, salinity values remained relatively low when compared to February 2008. Since the motions of the cyclonic gyre around the SAP are presumably highly intensified during winter mixing events, a larger quantity of waters from the western side of the Adriatic was entrapped within the gyre (Fig. 3). Drifter data documented that waters from western coastal area decrease towards east and can be included into the cyclonic gyre around the SAP (Taillandier et al., 2008). The cooling makes these Chl $a$-rich waters dense, forcing it to sink, whereas the surface layer of the cyclonic gyre around the SAP becomes poor in Chl $a$ (Fig. 3, February). During less intense vertical mixing in the water column, Chl $a$-rich waters might remain at the surface, whereby surface gyre waters of the SAP are marked with high Chl $a$ (Fig. 3, March).

The most intense growth of picoeukaryotes observed in February was generally supported by the highest DIN in the productive layer in comparison to the rest of the year. Although thermohaline properties around two stations were similar, the autotrophic biomass was much higher at P300 combined with much lower DIN in waters around this station in comparison to P1200. The lower DIN might indicate that LIW resided at P300 only a short time before water mixing and cooling have started. Moreover, lower DIN could also result from the occurrence of very abundant picoeukaryotes, Synechococcus and HP, which actively assimilate nitrate (Allen et al., 2001; Fawcett et al., 2011). This explanation might be additionally supported by a higher concentration of nitrite in these waters due to potential involvement of all three groups in nitrite production by nitrate reduction (Lomas and Lipschultz, 2006; Santoro et al., 2013). Nitrite accumulation closely paralleling the development of the phytoplankton biomass was also observed in the mixed layer during winter in the Red Sea (Al-Qutob et al., 2002). The marked decrease of Synechococcus towards open waters was regularly observed in south Adriatic (Cerino et al., 2012) as well as its dominance in picophytoplankton population (Šilović et al., 2011). In the post-convection phase during March the autotrophic biomass largely increased primarily in the area of the SAP (on average 5 times higher in respect to February) than on its margin (on average very similar to February) where LIW occupied entire water column. The onset of new production was most pronounced at P1200. In contrast, Synechococcus quickly responded to decreased nutrients due to LIW arrival and increased in abundance 
at P300. The increase in abundance of Synechococcus and the appearance of Prochlorococcus coincided with spreading of LIW into the entire productive layer during May and September, when oligotrophy of the area gradually increased. The dynamics and vertical distribution of the two genera appeared to be tightly coupled with inorganic nutrients, with a preference of lower DIN. However, while Synechococcus achieved higher abundances in nitrate and silicate absolute minima, Prochlorococcus accumulated along nitrite maxima. Therefore, the decrease in nutrient availability in the thick subsurface layer in May induced the bloom of Synechococcus, whereas Prochlorococcus appeared in the deeper layer. Prochlorococcus accumulated at pronounced nitricline in September, in areas of increased temperature. The cooccurrence of these two genera during summer and fall, as well as the deeper maximum of Prochlorococcus compared to Synechococcus appeared as a characteristic feature for oligotrophic environments (Mella-Flores et al., 2011), including South Adriatic waters (Šilović et al., 2011; Cerino et al., 2012).

The coupling of bacterial and phytoplankton activities found in this study were apparent and generally supports the idea that under oligotrophic conditions, co-variation between bacteria and dissolved organic carbon production occurs (Gasol et al., 1998; Ruiz-Gonzáles et al., 2012). Moreover, the increase or accumulation of autotrophic biomass highly stimulates prokaryotic heterotrophic production (Van Wambeke et al., 2004; Baltar et al., 2009, 2010; Orlić et al., 2013). Concomitantly with autotrophic biomass, prokaryotic heterotrophic production (calculated from Leu data using a conversion factor of $3.1 \mathrm{~kg} \mathrm{C} \mathrm{mol}^{-1}$ of Leu after Kirchman, 1993) increased markedly in

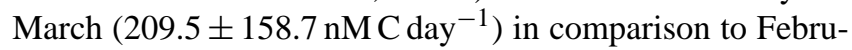
ary $\left(3.7 \pm 3.5 \mathrm{nMC} \mathrm{day}^{-1}\right)$ in the productive layer of both stations. In contrast, during 2007 when winter convection did not occur, Azzaro et al. (2012) found similar values in February $\left(\sim 50 \mathrm{nMC} \mathrm{day}^{-1}\right)$ and April $\left(\sim 40 \mathrm{nMCday}^{-1}\right)$. Apparently vigorous mixing and heat loss that occurred in February 2012 strongly but unfavorably influenced prokaryotic heterotrophic production, whereas introduced nutrients and enhanced new production enabled enormous substrate supply in productive zones, indirectly fueling prokaryotic heterotrophic production in March 2012.

Although both prokaryotic heterotrophic production rates increased significantly in March with respect to February, the relationship between the rates differed between stations. At P300 the increase in both rates was generally more synchronized ( $\mathrm{L} / \mathrm{T} \sim 25)$ or progressed with increased biomass production (L/T up to 140), whereas at P1200 much higher rates of cell replication than biomass production $(\mathrm{L} / \mathrm{T} \sim 5)$ were observed, particularly around DCM depth $(\mathrm{L} / \mathrm{T}<1)$. Consequently, at both stations heterotrophic prokaryote abundances followed the increase in respective autotrophic biomasses that were far more expressed around the SAP. Unbalanced growth of bacteria, when rates of protein synthesis and DNA synthesis are uncoupled, was usually observed in offshore regions, in deep samples of vertical profiles and during pulses of organic matter supply (Chin-Leo and Kirchman, 1990; Gasol et al., 1998, 2009). Accordingly, L/ T ratios from different aquatic habitats varied over a wide range, from 0.01 to $>200$ (Torréton and Dufour, 1996; Gasol et al., 1998; Hoppe et al., 2006; Longnecker et al., 2006; Gasol et al., 2009), with extreme values occurring in more extreme environments.

Temperature and resource supply are principal factors that influence bacterial growth and reproduction (Shiah and Ducklow, 1997), but variability of bacterial growth characteristics (as L/T ratio) is influenced by picocyanobacteria, particularly when abundant (Hietanen et al., 2002; Zubkov et al., 2003; Hoppe et al., 2006). Generally, our results (Table 2) showed that $T$ had greater effect on prokaryotic biomass production (Leu) while Chl $a$ (taken as a measure of substrate supply) affected more strongly cell replication rates (TdR). Thus the higher biomass production rate and increased values of L/T ratios at P300 might be induced by increased temperature of LIW and partly by much higher abundances of Synechococcus. These two factors, in addition to generally reduced substrate supply, probably led to significantly higher prokaryotic biomass production in waters influenced by LIW. Similar increase in both L/T ratio and the abundance of cyanobacteria were recorded in the Northern Adriatic during the period of 2003-2008, which coincided with overall increase in $S$ and $T$ in that area (Ivančić et al., 2010). In contrast, at $\mathrm{P} 1200$ lower $\mathrm{L} / \mathrm{T}$ ratios indicated that those bacteria maximized their reproduction, most probably due to the increase in Chl $a$. It was shown that bacteria favor DNA duplication over the protein synthesis in DCM depths where the maximal amount of dissolved organic matter to flow from photosynthesis was expected (Gasol et al., 1998). In addition, extremely low L/T ratios $(<1)$, as we got around DCM, were observed in mesopelagic areas affected by upwelling filament, where high bacterial activity (in terms of DNA synthesis rates) was assumed to be sustained by increased vertical flux or by direct intrusion of lateral carbon to mesopelagic waters (Gasol et al., 2009).

Our result showed that bacterial metabolic capacity decreases when substrate supply increases, both being in close correspondence with cell replication rate increase. This is in agreement with the finding that metabolic capacity consistently mediates the link between substrate supply and bacterial community metabolism (Comte and del Giorgio, 2009). In March the lowest metabolic capacity suggested that bacteria utilized freshly produced DOM released by phytoplankton. Such a relationship was also observed for surface NW Mediterranean waters (Sala et al., 2006). DOM produced in situ with high amino acid and amino sugar content is an important source of bioreactive organic matter, favoring the growth of bacteria specialized in the use of carbon sources derived from phytoplankton (Davis and Benner, 2005; Sala et al., 2008). Clear positive correlation of Chl $a$ with TdR 
suggested that bacteria rapidly adapted to changing substrate supply.

According to decreased input of fresh organic matter in May, the remaining organic matter from the bloom in March became less bioreactive but more complex. The conditions in May became more oligotrophic, therefore metabolic capacity significantly increased. This is in accordance with ecological theory of high metabolic diversity in oligotrophic areas (Frontier, 1985) where bacteria express higher plasticity in metabolic pathways in order to be able to exploit the changing and limiting carbon sources for growth (Sala et al., 2006, 2008). Although autotrophic biomass significantly decreased, cell replication rate was kept on the levels found for March. Apparently, such an increase in metabolic capacity requires adaptation of bacterial community composition with increased numbers of bacteria with versatile metabolic capabilities. During September, when the system was more stable, high metabolic capacity levels were sustained, while prokaryotic heterotrophic production rates were decreased but balanced. The highest metabolic capacity levels found in October 2011 suggested that the system was more oligotrophic in 2011 than in 2012. The differences in percentage substrate utilization between the two stations evident in March and May suggested that the composition of the DOM pool differed among these waters. These differences might be introduced by variable qualities of exudates attributable to phytoplankton origin and/or the amount and quality of grazing-derived DOM (Ghiglione et al., 2008; Ruiz-Gonzalez et al., 2012).

Co-variations of metabolic capacity in the productive and deeper layers suggested that the quality and amount of exported particles to the deeper layer depended on the intensity of autotrophic production in the productive layer. Such a relationship derived from positive coupling between downward fluxes of organic carbon and productivity in the same area (Boldrin et al., 2002; Turchetto et al., 2012). Since TdR values matched in both layers, bacterial function might be regulated by the same factors, that is, resource quality and availability. As the changes in bacteria metabolic potential are often linked to changes in bacterial community composition (Kirchman et al., 2004; Sala et al., 2006), the observed differences in utilization of substrates groups between the layers and between the stations might be associated with the differences in bacterial community composition.

The coupling between bacterial community composition and carbon metabolism was previously reported in some marine studies (Fuhrman et al., 2006; Alonso-Sáez et al., 2007). Furthermore, Fuhrman et al., (2006) demonstrated the repeatable temporal patterns in distribution and abundance of bacterial taxa, which was significantly influenced by a range of abiotic and biotic factors. However, bacterial community composition appeared to be similar in the productive and deeper layers between February and March, despite apparent differences in abiotic factors, prokaryotic heterotrophic abundance, production and metabolic capacity between 2 months. This observation could be explained by an"adjustment scenario", where change in community composition involves shifts in the relative abundance and activity of the existing phylotypes (Comte and del Giorgio, 2011). Since such bacterial communities generally have a high degree of metabolic/functional plasticity, bacterial community composition could remain stable under quite different environmental conditions. The lack of relationship between bacterial community composition and carbon metabolism, as we observed, generally suggests a high level of functional redundancy in the bacterial assemblage in carbon processing, at least at the phylogenetic resolution level analyzed by DGGE (Alonso-Sáez et al., 2008).

The bacterial community composition of the productive layer differed markedly from the bacterial community composition of the deeper layer, where mineralization processes took place and appear to be influenced by the physicochemical characteristics (DIN, $T, \mathrm{SiO}_{4}$ and $\mathrm{PO}_{4}$ ) of the related layers. Accordingly, in the productive layer, bacterial community composition of waters influenced by LIW were more similar to each other (mostly belonging to station P300), whereas bacterial community composition at P1200 were more different, followed by apparent phytoplankton composition changes (data not shown). Also, in the deeper layer, the increase in depth-related divergence between bacterial communities composition within seasons increased from winter to summer, being the highest in October 2011. These results are in accordance with studies that explained the vertical distribution of bacterial community by synergy of environmental parameters and interaction of bacteria with other plankton (Acinas et al., 1997; Ghiglione et al., 2008). An analysis employing the complex environmental data set in combination with microbial community structure will undoubtedly give more detailed insight into bacterial community composition changes with depth in this area.

\section{Conclusions}

Our results showed that winter convection events and LIW have different roles in the distribution and function of the picoplankton community. Although the winter convection induced a strong increase in prokaryotic heterotrophic production in March, an enormous increase in the autotrophic biomass, followed by a disruption of a close correspondence between Leu and $\mathrm{TdR}$ incorporation rates $(\mathrm{L} / \mathrm{T}<1)$ occurred only in the center of the SAP beyond the reach of LIW. At the SAP margin LIW attenuated winter convection effects. In general, the waters affected by LIW were characterized by decreased DIN and autotrophic biomasses and by increased abundances of Synechococcus and prokaryotic biomass production rates balanced with cell replication. Furthermore, we showed that metabolic capacity is a trait of the bacterial community, independent of environmental conditions and strongly linked to cell replication rate and substrate supply. 
Metabolic capacity indicated a general increase in trophic states after winter convection events, although autotrophic biomasses in comparable periods, October 2011 and September 2012, were similar. Bacterial community composition appeared to be strongly influenced by physico-chemical characteristics of waters and environmental forcing. Our results reinforce the significance of two oceanographic phenomena of the Southern Adriatic, which might play a key role in the control of the total production of the Adriatic Sea, as both can change the relative importance of the River Po freshwater input in this vital process.

\section{The Supplement related to this article is available online at doi:10.5194/bg-11-2645-2014-supplement.}

Acknowledgements. The financial support was provided by the Ministry of Science, Education and Sports of the Republic of Croatia (Projects: 275-0000000-3186, 0982705-2729) and the Croatian Science Foundation (project BABAS). We sincerely thank Ksenija Matošović for help in the field and laboratory, and the crew of RV Naše more for their collaboration and support. We highly appreciate the detailed and valuable comments of the anonymous reviewers and G. Herndl on our manuscript.

Edited by: G. Herndl

\section{References}

Acinas, S. G., Rodriguez-Valera, F., and Pedros-Alio, C.: Spatial and temporal variation in marine bacterioplankton diversity as shown by RFLP fingerprinting of PCR amplified 16S rDNA, FEMS Microbiol. Ecol. 24, 27-40, 1997.

Al-Qutob, M., Hase, C., Tilzer, M. M., and Lazar, B.: Phytoplankton drives nitrite dynamics in the Gulf of Aqaba, Red Sea, Mar. Ecol.-Prog. Ser., 239, 233-239, 2002.

Allen, A. E., Booth, M. G., Frischer, M. E., Verity, P. G., Zehr, J. P., and Zani, S.: Diversity and detection of nitrate assimilation genes in marine bacteria, Appl. Environ. Microbiol., 67, 53435348, 2001.

Alonso-Sáez, L., Arístegui, J., Pinhassi, J., Gómez-Consenau, L., González, J. M., Vaqué, D., Agusti, S., and Gasol, J. M.: Bacterial assemblage structure and carbon metabolism along the productivity gradient in the NE Atlantic Ocean, Aquat. Microb. Ecol., 46, 43-53, 2007.

Alonso-Sáez, L., Vázquez-Domínguez, E., Cardelús, C., Pinhassi, J., Sala, M. M., Lekunberri, I., Balagué, V., Vila-Costa, M., Unrein, F., Massana, R., Simó, R., and Gasol, J. M.: Factors controlling the year-round variability in carbon flux through bacteria in a coastal marine systems, Ecosystems, 11, 397-409, 2008.

Artegiani, A., Paschini, E., Russo, A., Bregant, D., Raicich, F., and Pinardi, N.: The Adriatic Sea General Circulation. Part I: airsea interactions and water mass structure, J. Phys. Oceanogr., 27, 1492-1514, 1997.
Azzaro, M., La Ferla, R., Maimone, G., Monticelli, L. S., Zaccone, R., and Civitarese, G.: Prokaryotic dynamics and heterotrophic metabolism in a deep convection site of Eastern Mediterranean Sea (the Southern Adriatic Pit), Cont. Shelf. Res., 44, 106-118, 2012.

Baltar, F., Arístegui, J., Montero, M. F., Espino, M., Gasol, J. M., and Herndl, G. J.: Mesoscale variability modulates seasonal changes in the trophic structure of nano- and picoplankton communities across the NW Africa-Canary Islands transition zone, Prog. Oceanogr., 83, 180-188, 2009.

Baltar, F., Arístegui, J., Gasol, J. M., Lekunberri, I., and Herndl, G. J.: Mesoscale eddies: hotspots of prokaryotic activity and differential community structure in the ocean, ISME J., 4, 975-988, 2010.

Batistić, M., Jasprica, N., Carić, M., Čalić, M., Kovačević, V., Garić R., Njire J., Mikuš J., and Bobanović-Ćolić, S.: Biological evidence of a winter convection event in the South Adriatic: A phytoplankton maximum in the aphotic zone, Cont. Shelf Res., 44, 57-71, 2012.

Bensi, M., Cardin, V., Rubino, A., Notarstefano, G., and Poulain, P. M.: Effects of winter convection on the deep layer of the Southern Adriatic Sea in 2012, J. Geophys. Res., 118, 6064-6075, doi:10.1002/2013JC009432, 2013.

Boldrin, A., Miserocchi, S., Rabitti, S., Turchetto, M. M., Balboni, V., and Socal, G.: Particulate matter in the southern Adriatic and Ionian Sea: characterization and downward fluxes, J. Mar. Syst., 33-34, 389-410, 2002.

Boström, K. H., Simu, K., Hagström, Å., and Riemann, L.: Optimization of DNA extraction for quantitative marine bakterioplankton community analysis, Limnol. Oceanogr.-Methods, 2, 365-373, 2004.

Cerino, F., Bernardi-Aubry, F., Coppola, J., La Ferla, B., Maimone, G. Socal, G., and Totti, C.: Spatial and temporal variability of pico-, nano- and microphytoplankton in the Southern Adriatic Sea (Mediterranean Sea), Cont. Shelf Res., 44, 94-105, 2012.

Chin-Leo, G. and Kirchman, D. L.: Unbalanced growth in natural assemblages of marine bacterioplankton, Mar. Ecol.-Prog. Ser., $63,1-8,1990$.

Civitarese, G. and Gačić, M.: Had the Eastern Mediterranean Transient an Impact on the New Production in the Southern Adriatic? Geophys. Res. Lett., 28, 1627-1630, 2001.

Civitarese, G., Gačić, M., Vetrano, A., Boldrin, A., Bregant, D., Rabitti, S., and Souvermezoglou, E.: Biogeochemical fluxes through the Strait of Otranto (Eastern Mediterranean), Cont. Shelf Res., 18, 773-789, 1998.

Civitarese, G., Gačić, M., Cardin, V., and Ibello, V.: Winter convection continues in the warming Southern Adriatic, Eos Trans. AGU, 86, 445-451, 2005.

Civitarese, G., Gačić, M., Lipizer, M., and Borzelli, G. L. E.: On the impact of the bimodal oscillating system (BiOS) on the biogeochemistry and biology of the Adriatic and IonianSeas (EasternMediterranean), Biogeosciences, 7, 3987-3997, doi:10.5194/bg7-3987-2010, 2010

Comte, J. and del Giorgio, P. A.: Links between resources, C metabolism and the major components of bacterioplankton community structure across a range of freshwater ecosystem, Environ. Microbiol., 11, 1704-1716, 2009. 
Comte, J. and del Giorgio, P. A.: Linking the patterns of change in composition and function in bacterioplankton successions along environmental gradients, Ecology, 91, 1466-1476, 2010.

Comte, J. and del Giorgio, P. A.: Composition influences the pathway but not the outcome of the metabolic response of bacterioplankton to resource shifts, PLoS ONE, 6, e25266, doi:10.1371/journal.pone.0025266, 2011.

Comte, J., Fanteux, L., and del Giorgio, P. A.: Links between metabolic plasticity and functional redundancy in freshwater bacterioplankton communities, Front. Microbiol., 4, 112, doi:10.3389/fmicb.2013.00112, 2013.

Davis, J. and Benner, R.: Seasonal trends in the abundance, composition and bioavailability of particulate and dissolved organic matter in the Chukchi/Beaufort Seas and western Canada Basin, Deep-Sea Res. Pt. II, 52, 3396-3410, 2005.

del Giorgio, P. A., Gasol, J. M., Vaqué, D., Mura, P., Agustí, S., and Duarte, C. M.: Bacterioplankton community structure: protists control net production and the proportion of active bacteria in a coastal marine community, Limnol. Oceanogr., 41, 1169-1179, 1996.

Fawcett, S. E., Lomas, M., Casey, J. R., Ward, B. B., and Sigman, D. M.: Assimilation of upwelled nitrate by small eukaryotes in the Sargasso Sea, Nat. Geosci., 4, 717-722, 2011.

Frontier, S.: Diversity and structure in aquatic ecosystems, Oceanogr. Mar. Biol., 23, 253-312, 1985.

Fuhrman, J. A. and Azam, F.: Thymidine incorporation as a measure of heterotrophic bacterioplankton production in marine surface waters; evaluation and field results, Mar. Biol., 66, 109-120, 1982.

Fuhrman, J. A., Hewson, I., Schwalbach, M. S., Steele, J. A., Brown, M. V., and Naeem, S.: Annually reoccurring bacterial communities are predictable from ocean conditions, P. Natl. Acad. Sci., 103, 13104-13109, 2006.

Gačić, M. and Civitarese, G.: Introductory notes on the South Adriatic oceanography, Cont. Shelf Res., 44, 2-4, 2012.

Gačić, M., Marullo, S., Santoleri, R., and Bergamasco, A.: Analysis of seasonal and interannual variability of the sea surface temperature in the Adriatic Sea from AVHRR data (1984-1992), J. Geophys. Res., 102, 937-946, 1997.

Gačić, M., Lascaratos, A., Manca, B. B., and Mantziafou, A.: Adriatic deep water interaction with the Eastern Mediterranean Sea, in: Physical Oceanography of the Adriatic Sea, edited by: Cushman-Roisin, B., Gačić, M., Poulain, P. M., and Artegiani, A., Kluwer Academic Publishers, Dordrecht, 111-142, 2001.

Gačić, M., Civitarese, G., Miserocchi, S., Cardin, V., Crise, A., and Mauri, E.: The open-ocean convection in the Southern Adriatic: a controlling mechanism of the spring phytoplankton bloom, Cont. Shelf Res., 22, 1897-1908, 2002.

Garland, J. L. and Mills, A. L.: Classification and characterization of heterotrophic microbial communities on the basis of patterns of community-level-sole-carbon-source-utilisation. Appl. Environ. Microbiol., 57, 2351-2359, 1991.

Gasol, J. M., Doval, M. D., Pinhassi, J., Calderón-Paz, J. I., GuixaBoixareu, N., Vaqué, D., and Pedrós-Alió, C.: Diel variations in bacterial heterotrophic activity and growth in the northwestern Mediterranean Sea, Mar. Ecol.-Prog. Ser., 164, 107-124, 1998.

Gasol, J. M., Alonso-Sáez, L., Vaqué, D., Baltar, F., Calleja, M. L. 1., Duarte, C. M., and Arístegui, J.: Mesopelagic prokaryotic bulk and single-cell heterotrophic activity and community composi- tion in the NW Africa-Canary Islands coastal-transition zone, Prog. Oceanogr., 83, 189-196, 2009.

Ghiglione, J. F., Palacios, C., Marty, J. C., Mevel, G., Labrune, C., Conan, P., Pujo-Pay, M., Garcia, N., and Goutx, M.: Role of environmental factors for the vertical distribution $(0-1000 \mathrm{~m})$ of marine bacterial communities in the NW Mediterranean Sea, Biogeosciences, 5, 1751-1764, doi:10.5194/bg-5-1751-2008, 2008.

Hietanen, S., Lehtimaeki, J. M., Tuominen, I., Sivonen, K., and Kuparinen, J.: Nodularia spp. (Cyanobacteria) incorporates leucine but not thymidine: importance for bacterial-production measurements, Aquat. Microb. Ecol., 28, 99-104, 2002.

Holm-Hansen, O., Lorenzen, C. J., Holmes, R. W., and Strickland, J. D. H.: Fluorometric determination of chlorophyll, J. Conseil., 301, 3-15, 1965.

Hoppe, H.-G., Gocke, K., Koppe, R., and Kraus, G.: Changing bacterioplankton growth characteristics on a large spatial scale: oligotrophic versus mesotrophic ocean, Mar. Ecol.-Prog. Ser., 323, 21-33, 2006.

Ivančić, I. and Degobbis, D.: An optimal manual procedure for ammonia analysis in natural waters by the indophenol blue method, Water Res., 18, 1143-1147, 1984.

Ivančić, I., Fuks, D., Najdek, M., Blažina, M., Devescovi, M., Šilović, T., Paliaga, P., and Orlić, S.: Long-term changes in heterotrophic prokaryotes abundance and growth characteristics in the northern Adriatic Sea, J. Mar. Syst., 82, 206-216, 2010.

Kirchman, D., K'nees, E., and Hodson, R.: Leucine incorporation and its potential as a measure of protein synthesis by bacteria in natural aquatic systems, Appl. Environ. Microbiol., 49, 599-607, 1985.

Kirchman, D. L.: Leucine incorporation as a measure of biomass production by heterotrophic bacteria, in: Handbook of methods in aquatic microbial ecology, edited by: Kemp, P. F., Sherr, B. F., Sherr, E. B., and Cole, J. J., Lewis Publishers, Boca Raton, 509-512, 1993.

Kirchman, D. L., Dittel, A. I., Findlay, S. E. G., and Fischer, D.: Changes in bacterial activity and community structure in response to dissolved organic matter in the Hudson River, New York, Aquat. Microb. Ecol., 35, 243-257, 2004.

Lomas, M. W. and Lipschultz, F.: Forming the primary nitrite maximum: Nitrifiers or phytoplankton?, Limnol. Oceanogr., 51, 2453-2467, 2006.

Longnecker, K., Sherr, B. F., and Sherr, E. B.: Variation in cellspecific rates of leucine and thymidine incorporation by marine bacteria with high and with low nucleic acid content off the Oregon coast, Aquat. Microb. Ecol., 43, 113-125, 2006.

Marie, D., Partensky, F., Jacquet, S., and Vaulot, D.: Enumeration and cell cycle analysis of natural populations of marine picoplankton by flow cytometry using the nucleic acid stain SYBR Green I, Appl. Environ. Microbiol., 63, 186-193, 1997.

Mella-Flores, D., Mazard, S., Humily, F., Partensky, F., Mahé, F., Bariat, L., Courties, C., Marie, D., Ras, J., Mauriac, R., Jeanthon, C., Mahdi Bendif, E., Ostrowski, M., Scanlan, D. J., and Garczarek, L.: Is the distribution of Prochlorococcus and Synechococcus ecotypes in the Mediterranean Sea affected by global warming?, Biogeosciences, 8, 2785-2804, doi:10.5194/bg-82785-2011, 2011.

Mihanović, H., Vilibić, I., Carniel, S., Tudor, M., Russo, A., Bergamasco, A., Bubić, N., Ljubešić, Z., Viličić, D., Boldrin, A., Malačić, V., Celio, M., Comici, C., and Raicich, F.: Exceptional 
dense water formation on the Adriatic shelf in the winter of 2012, Ocean Sci., 9, 561-572, doi:10.5194/os-9-561-2013, 2013.

Orlić ,S., Najdek, M., Supić, N., Ivančić, I., Fuks, D., Blažina, M., Šilović, T., Paliaga, P., Godrijan, J., and Marić, D.: Structure and variability of microbial community at transect crossing a double gyre structure (north-eastern Adriatic Sea), Aquat. Microb. Ecol., 69, 193-203, 2013.

Ruiz-Gonzalez, C., Lefort, T., Massana, R., Simó, R., and Gasol, J. M.: Diel changes in bulk and single-cell bacterial heterotrophic activity in winter surface waters of the northwestern Mediterranean Sea, Limnol. Oceanogr., 57, 29-42, 2012.

Sala, M. M., Estrada, M., and Gasol, J. M.: Seasonal changes in the functional diversity of bacterioplankton in contrasting coastal environments of the NW Mediterranean, Aquat. Microb. Ecol., 44, 1-9, 2006.

Sala, M. M., Terrado, R., Lovejoy, C., Unrein, F., and Pedrós-Alió, C.: Metabolic diversity of heterotrophic bacterioplankton over winter and spring in the coastal Arctic Ocean, Environ. Microbiol., 10, 942-949, 2008.

Santoro, A. E., Sakamoto, C. M., Smith, J. M., Plant, J. N., Gehman, A. L., Worden, A. Z., Johnson, K. S., Francis, C. A., and Casciotti, K. L.: Measurements of nitrite production in and around the primary nitrite maximum in the central California Current, Biogeosciences, 10, 7395-7410, doi:10.5194/bg-10-7395-2013, 2013.

Shiah, F. K. and Ducklow, H. W.: Bacterioplankton growth responses to temperature and chlorophyll variations in estuaries measured by thymidine: leucine incorporation ratio, Aquat. Microb. Ecol., 13, 151-159, 1997.

Smith, D. C. and Azam, F.: A simple, economical method for measuring bacteria protein synthesis rates in seawater using $3 \mathrm{H}-$ leucine, Mar. Microb. Food Webs, 6, 107-114, 1992.

Strickland, J. D. H. and Parsons, T. R.: A practical handbook of seawater analysis, Bull. Fish Res. Bd. Canada, 167, 1-310, 1972.

Šilović, T., Ljubešić, Z., Mihanović, H., Olujić, G., Terzić, S., Jaksić, Ž., and Viličić, D.: Picoplankton composition related to thermohaline circulation: The Albanian boundary zone (southern Adriatic) in late spring, Estuar. Coast. Shelf Sci., 91, 521-525, 2011.
Taillandier, V., Griffa, A., Poulain, P. M., Signell, R., Chiggiato, J., and Carniel S.: Variation analysis of drifter positions and model outputs for the reconstruction of surface currents in the central Adriatic during fall 2002, J. Geophys. Res., 113, C04004, doi:10.1029/2007JC004148, 2008.

Torreton, J. P. and Dufour, P.: Bacterioplankton production determined by DNA synthesis, protein synthesis, and frequency of dividing cells in Tuamotu Atoll lagoons and surrounding ocean, Microb. Ecol., 32, 185-202, 1996.

Turchetto, M., Boldrin, A., Langone, L., and Miserocchi, S.: Physical and biogeochemical processes controlling particle fluxes variability and carbon export in the Southern Adriatic, Cont. Shelf Res., 44, 72-82, 2012.

Van Wambeke, F., Lefèvre, D., Prieur, L., Sempéré, R., Bianchi, M., Oubelkheir, K., and Bruyant, F.: Distribution of microbial biomass, production, respiration, dissolved organic carbon and factors controlling bacterial production across a geostrophic front (Almeria-Oran, SW Mediterranean Sea), Mar. Ecol.-Prog. Ser., 269, 1-15, 2004.

Vilibić, I. and Orlić, M.: Adriatic water masses, their rates of formation and transport through the Otranto Strait, Deep-Sea Res. Pt. I, 49, 1321-1340, 2002.

Vilibić, I. and Šantić, D.: Deep water ventilation traced by Synechococcus cyanobacteria, Ocean Dynam., 58, 119-125, 2008.

Zaccone, R., Monticelli, L. S., Seritti, A., Santinelli, C., Azzaro, M., Boldrin, A., LaFerla, R., and Ribera d'Alcala, M.: Bacterial processes in the intermediate and deep layers of the Ionian Sea in winter 1999: vertical profiles and their relationship to the different water masses, J. Geophys. Res., 108, 8117, doi:10.1029/2002JC001625, 2003.

Zubkov, M. V., Fuchs, B. M., Tarran, G. A., Burkill, P. H., and Amann, R. High rate of uptake of organic nitrogen compounds by Prochlorococcus Cyanobacteria as a key to their dominance in oligotrophic oceanic waters, Appl. Environ. Microbiol., 69, 1299-1304, 2003. 